Review

\title{
Solid-State Preparation of Metal and Metal Oxides Nanostructures and Their Application in Environmental Remediation
}

\author{
Carlos Diaz $^{1, *}$, Maria Luisa Valenzuela ${ }^{2}$ and Miguel Á. Laguna-Bercero ${ }^{3}(\mathbb{D}$ \\ 1 Departamento de Química, Facultad de Ciencias, Universidad de Chile, Las Palmeras 3425, Nuñoa, \\ Casilla 653, Santiago 7800003, Chile \\ 2 Instituto de Ciencias Químicas Aplicadas, Grupo de Investigación en Energía y Procesos Sustentables, \\ Facultad de Ingeniería, Universidad Autónoma de Chile, Av. El Llano Subercaseaux 2801, \\ Santiago 8900000, Chile; maria.valenzuela@uautonoma.cl \\ 3 Instituto de Nanociencia y Materiales de Aragón (INMA), CSIC-Universidad de Zaragoza C/Pedro Cerbuna 12, \\ 50009 Zaragoza, Spain; malaguna@unizar.es \\ * Correspondence: cdiaz@uchile.cl
}

Citation: Diaz, C.; Valenzuela, M.L.; Laguna-Bercero, M.Á. Solid-State Preparation of Metal and Metal Oxides Nanostructures and Their Application in Environmental Remediation. Int. J. Mol. Sci. 2022, 23, 1093. https://doi.org/10.3390/ ijms23031093

Academic Editor: David Mills

Received: 6 November 2021

Accepted: 13 December 2021

Published: 20 January 2022

Publisher's Note: MDPI stays neutral with regard to jurisdictional claims in published maps and institutional affiliations.

Copyright: (c) 2022 by the authors Licensee MDPI, Basel, Switzerland. This article is an open access article distributed under the terms and conditions of the Creative Commons Attribution (CC BY) license (https:// creativecommons.org/licenses/by/ $4.0 /)$.

\begin{abstract}
Nanomaterials have attracted much attention over the last decades due to their very different properties compared to those of bulk equivalents, such as a large surface-to-volume ratio, the size-dependent optical, physical, and magnetic properties. A number of solution fabrication methods have been developed for the synthesis of metal and metal oxides nanoparticles, but few solid-state methods have been reported. The application of nanostructured materials to electronic solid-state devices or to high-temperature technology requires, however, adequate solid-state methods for obtaining nanostructured materials. In this review, we discuss some of the main current methods of obtaining nanomaterials in solid state, and also we summarize the obtaining of nanomaterials using a new general method in solid state. This new solid-state method to prepare metals and metallic oxides nanostructures start with the preparation of the macromolecular complexes chitosan $\mathrm{Xn}$ and PS-co-4-PVP.MXn as precursors (X = anion accompanying the cationic metal, $\mathrm{n}=$ is the subscript, which indicates the number of anions in the formula of the metal salt and PS-co-4-PVP = poly(styrene-co-4-vinylpyridine)). Then, the solid-state pyrolysis under air and at $800{ }^{\circ} \mathrm{C}$ affords nanoparticles of $\mathrm{M}^{\circ}, \mathrm{M}_{\mathrm{x}} \mathrm{O}_{\mathrm{y}}$ depending on the nature of the metal. Metallic nanoparticles are obtained for noble metals such as $\mathrm{Au}$, while the respective metal oxide is obtained for transition, representative, and lanthanide metals. Size and morphology depend on the nature of the polymer as well as on the spacing of the metals within the polymeric chain. Noticeably in the case of $\mathrm{TiO}_{2}$, anatase or rutile phases can be tuned by the nature of the $\mathrm{Ti}$ salts coordinated in the macromolecular polymer. A mechanism for the formation of nanoparticles is outlined on the basis of TG/DSC data. Some applications such as photocatalytic degradation of methylene by different metal oxides obtained by the presented solid-state method are also described. A brief review of the main solid-state methods to prepare nanoparticles is also outlined in the introduction. Some challenges to further development of these materials and methods are finally discussed.
\end{abstract}

Keywords: metal oxides; nanostructures; solid state; photocatalyst; ambient remediation

\section{Introduction}

Over the past few decades, nanoscale particles have caused much interest due to their distinct chemical, physical and biological properties. A variety of nanoparticles (NPs) with various shapes such as spheres, nanotubes, nanohorns, and nanocages, made different materials, from organic dendrimers, liposomes, gold, carbon, semiconductors, silicon to iron oxide, have already been fabricated and explored in many scientific fields, including chemistry, material sciences, physics, medicine, and electronics [1-5]. In this sense, a number of solution methods have been developed for the synthesis of metal and metal oxides 
nanoparticles [2,3], but few solid states have been reported [6]. The application of nanostructured materials to electronic solid-state devices or to high-temperature technology requires, however, adequate solid-state methods for obtaining nanostructured materials [7-11]. For instance, recent studies reported that the evaporation of solvent to obtain Au nanoparticles in solid state (for adequate incorporation to a solid-state device) results in 3D Au superstructures with properties different to those of Au nanostructures [12]. Thus, solvent-less synthesis of nanostructures is highly significant due to its economical, eco-friendly, and industrially viable nature. Then, the development of new solid-state methods to prepare metallic nanostructured materials is a constant challenge. We have previously informed a new solid-state method to synthesize metallic nanostructures nanomaterials from the pyrolysis of metallic and organometallic derivatives of poly and oligophosphazene under air at $800{ }^{\circ} \mathrm{C}$ [13-17]. Nanostructured metals (M), metal oxides $\left(\mathrm{M}_{\mathrm{x}} \mathrm{O}_{\mathrm{y}}\right)$, and salts $\left(\mathrm{M}_{\mathrm{x}} \mathrm{P}_{\mathrm{y}} \mathrm{O}_{\mathrm{z}}\right.$, where $\mathrm{P}=$ malonates, succinates, etc.) are obtained, depending on the nature of the metal. Another method when the respective metallic or organometallic derivative is not possible to prepare uses mixtures such as $\mathrm{MLn} /\left[\mathrm{NP}\left(\mathrm{O}_{2} \mathrm{C}_{12} \mathrm{H}_{8}\right)\right]_{3}$ [18-20]. In this case, pure phase metallic nanoparticles are obtained. However, in several of these systems, the $\mathrm{M}$ or $\mathrm{M}_{\mathrm{x}} \mathrm{O}_{\mathrm{y}}$ phase is accompanied by a phosphate phase. These methods have been discussed in detail in several publications [13-23]. In this chapter, we will discuss a novel preparation method of metallic and metal oxides nanostructured particles starting from the macromolecular chitosan-MXn and PS-co-4-PVP.MXn precursor and subsequent solid-state pyrolysis at $800{ }^{\circ} \mathrm{C}$ under air (see Figure 1), including their application in environmental remediation. In addition, we will present a brief discussion of some recent solid-state methods to prepare metallic and metal oxides nanoparticles.

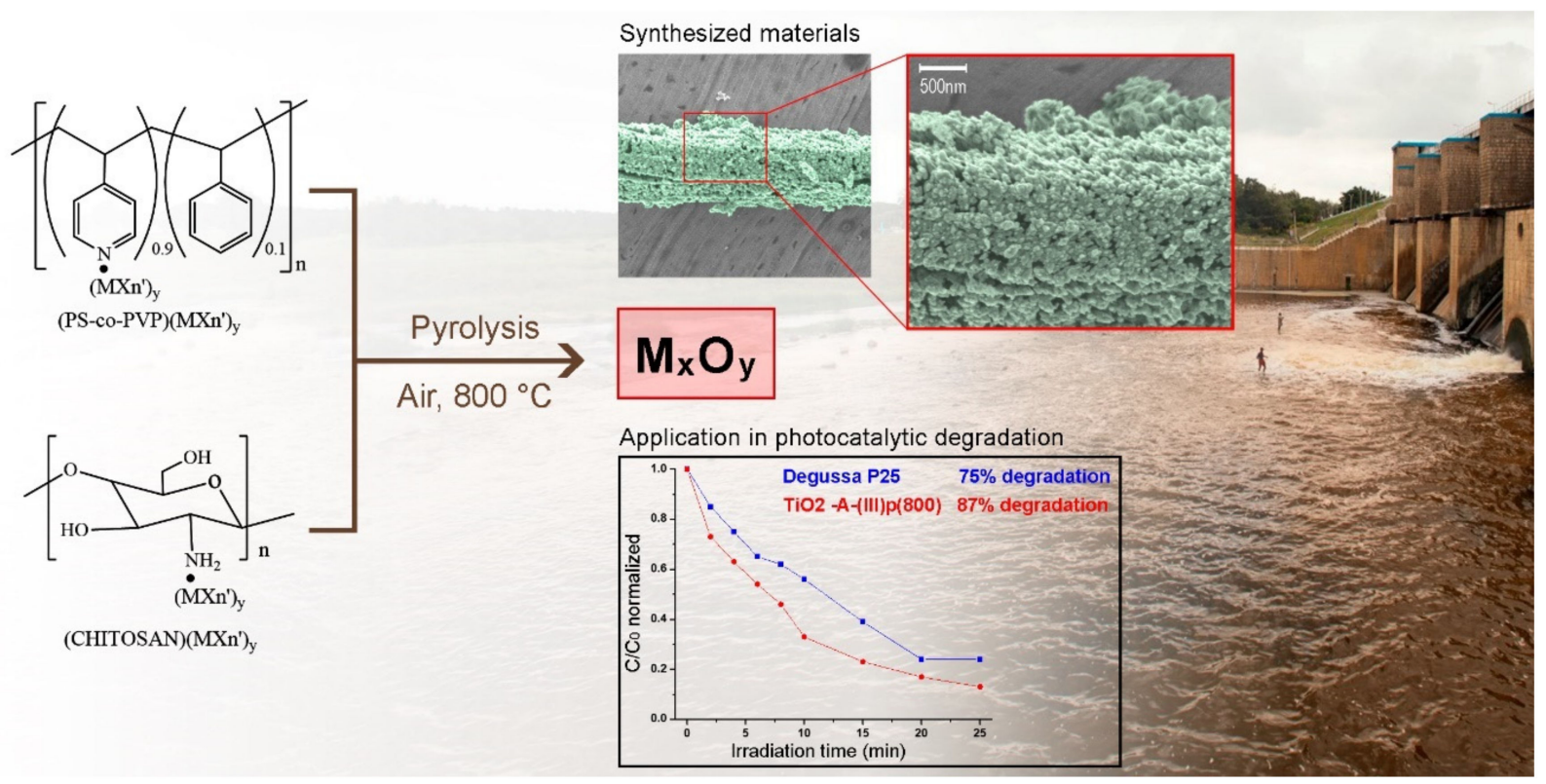

Figure 1. Schematic representation of the solid-state method and its application in environmental remediation.

In this review, we first present studies of different methods for obtaining solid-state nanomaterials collected from the literature. In addition, a summary of the results obtained in the preparation of nanomaterials using our developed solid-state method is also presented. Finally, results regarding their application in photocatalysis will be discussed for the different nanostructured metal oxides. 


\section{A General Survey of Methods for Preparation of Metal Oxide Nanoparticles}

\subsection{The Korgel's Method}

This method consists of the thermolysis of Metal-Thiolate complexes. The products are metal-sulfide nanoparticles with monodispersed and shape distributions. Briefly, the precursor is prepared by a biphasic reaction between a metallic salt and dodecanethiol using sodium octanoate as a phase transfer catalyst to solubilize the metal cationic in a water/chloroform mixture (see Figure 2). The aqueous phase is discarded, and the organic solvent is evaporated. The waxy solid is heated in the air up to $140-240{ }^{\circ} \mathrm{C}$ depending on the metal used. Then, the material is redispersed in chloroform to eliminate the rest of the dodecanethiol stabilizer. Different metal-sulfide nanoparticles such as $\mathrm{Cu}_{2} \mathrm{~S}[24,25]$, $\mathrm{NiS}$ [26], or $\mathrm{Bi}_{2} \mathrm{~S}_{3}$ [27], among others, were prepared using this method. In another approach, thermolysis of the related stearate $\mathrm{M}\left(\mathrm{OOCC}_{17} \mathrm{H}_{33}\right)_{\mathrm{n}}$ affords the respective metal oxides [28].

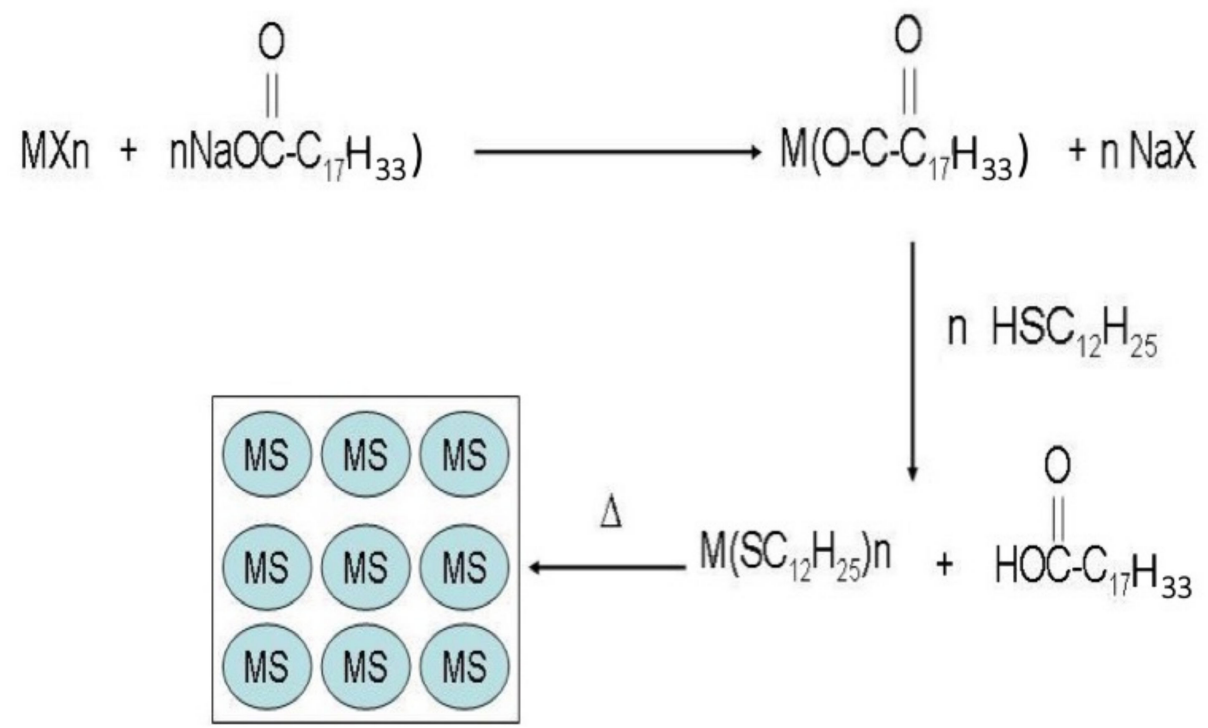

Figure 2. Squematic representation of Korgel's method. The first two steps are in solution and correspond to the preparation of the solid precursor. The third step corresponds to the solid thermolysis of the $\mathrm{M}\left(\mathrm{SC}_{12} \mathrm{H}_{25}\right)_{\mathrm{n}}$ precursor.

\subsection{The Molecular and Macromolecular Complex Decomposition Method}

This method consists simply of the solid-state thermal decomposition of a molecular complex under air at temperatures about $800{ }^{\circ} \mathrm{C}$. Several examples of decomposition of [Ni(en) 3 ] $\left(\mathrm{NO}_{3}\right)_{2}$ [29], Nickel dimethylglyoximate [30], [bis(2-hydroxy-1-naphtaldehyde) manganese(II)] [31], $\mathrm{MnOOH}$ (in presence of $\mathrm{Mn}_{3} \mathrm{O}_{4}$ ) are used to produce $\mathrm{NiO}$ and $\mathrm{Mn}_{3} \mathrm{O}_{4}$, respectively [32]. In addition, $\mathrm{ZnO}$ was obtained from thermolysis of bis(acetylacetonate) $\mathrm{Zn}$ (II) [33] and $\mathrm{Co}_{3} \mathrm{O}_{4}$ from solid-state pyrolysis of the $\left[\mathrm{Co}\left(\mathrm{NH}_{3}\right)_{6}\right]\left(\mathrm{NO}_{3}\right)_{2}$ complex [34].

A most general solid-state method to prepare $\mathrm{Mn}, \mathrm{Fe}, \mathrm{Co}, \mathrm{Ni}, \mathrm{Cu}$, and $\mathrm{Zn}$ oxides has been reported from the solid-state decomposition of the metal transition malonates $\mathrm{MCH}_{2} \mathrm{C}_{2} \mathrm{O}_{4} \cdot \times \mathrm{H}_{2} \mathrm{O}$ and transition succinates $\mathrm{M}\left(\mathrm{CH}_{2}\right)_{2} \mathrm{C}_{2} \mathrm{O}_{4} \cdot \mathrm{xH}_{2} \mathrm{O}$ [35].

Metal polymeric materials have also been used as precursors of nanostructured metal oxides. For instance, pyrolysis of the $\left[\mathrm{Ru}(\mathrm{CO})_{4}\right]_{\mathrm{n}}$ polymer affords ruthenium nanofibers [36]. Pyrolysis of poly(ferrocenylsilanes) affords $\alpha$-Fe nanoparticles with $20 \pm 5 \AA$ in size [37]. In addition, pyrolysis of poly(ferrocenylsilanes) yields interesting ferromagnetic ceramic composites at $500-1000^{\circ} \mathrm{C}$ containing Fe particles in a $\mathrm{SiC} / \mathrm{C}$ matrix [38].

Metal ligand coordination polymers have also been proposed as useful precursors of nanostructured metal oxides. Pyrolysis at $800{ }^{\circ} \mathrm{C}$ of a Ga-acetate polymer, $\{[\mathrm{Ga}(\mu-\mathrm{OH})(\mu-$ $\left.\left.\left.\mathrm{O}_{2} \mathrm{CCH}_{3}\right)_{2}\right] \cdot \mathrm{HOAc} \cdot \mathrm{H}_{2} \mathrm{O}\right\}_{n}$ gives rise to nanostructured $\mathrm{Ga}_{2} \mathrm{O}_{3}$ [39]. 
Furthermore, pyrolysis of some miscellaneous solid precursors has been reported. The Os clusters $\mathrm{Os}_{3}(\mathrm{CO})_{12}(\mathbf{1}), \mathrm{Os} 4-(\mu-\mathrm{H})_{4}(\mathrm{CO})_{12}(2)$, and $\mathrm{Os}_{6}(\mathrm{CO})_{18}(3)$, whose schematic representation of their skeletal is shown in Figure 3 [40].

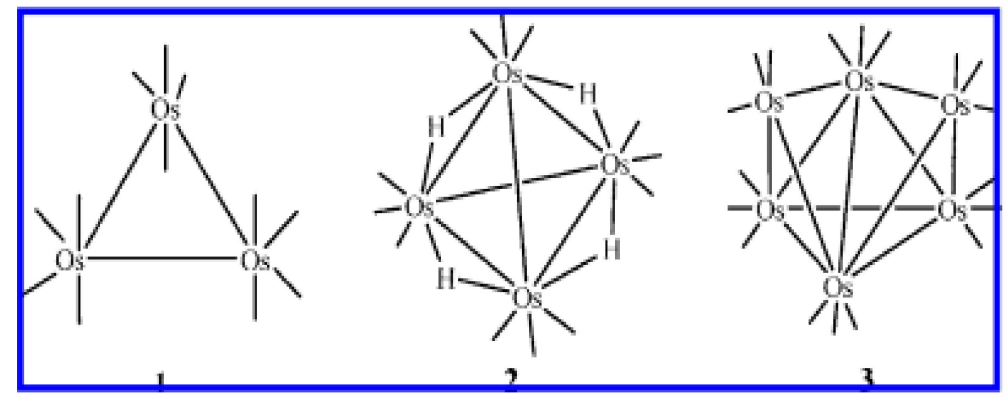

Figure 3. Schematic representation of the structures of $\mathrm{Os}_{3}(\mathrm{CO})_{12}(\mathbf{1})$, Os4- $(\mu-\mathrm{H})_{4}(\mathrm{CO})_{12}(\mathbf{2})$, and $\mathrm{Os}_{6}(\mathrm{CO})_{18}$ (3). Adapted from reference [40].

Pyrolysis of these clusters affords Os nanoparticles in the 1 to $10 \mathrm{~nm}$ size range. A similar approach was reported using ruthenium clusters, where $\mathrm{Ru}$ nanoparticles were obtained.

This method was also proposed for the fabrication of different perovskites. For example, $\mathrm{LaMnO}_{3 \pm \delta}$ was prepared by thermal treatment of the LaMnOx/C precursors [41]. The solid-state gelation synthesis route was extended to a wide range of interesting perovskite oxides, including $\mathrm{LaMnO}_{3}, \mathrm{LaFeO}_{3}, \mathrm{LaNiO}_{3}, \mathrm{LaCoO}_{3}, \mathrm{La}_{0.5} \mathrm{Sr}_{0.5} \mathrm{CoO}_{3}$, and $\mathrm{La}_{0.5} \mathrm{Sr}_{0.5} \mathrm{Co}_{0.5} \mathrm{Fe}_{0.5} \mathrm{O}_{3}$.

Other composites, including perovskites such as $\mathrm{CsPbBr}-\mathrm{Al}_{2} \mathrm{O}_{3}$, were synthetized by calcination of the mixture $\mathrm{CsBr} / \mathrm{PbBr}_{2} / \mathrm{AIP}=1: 1: 30$ at $800{ }^{\circ} \mathrm{C}$ for 10 min under a nitrogen atmosphere. The as-obtained perovskites possessed a high quantum yield up to $70 \%$, narrow emission line width of $25 \mathrm{~nm}$, and outstanding thermal stability [42].

In addition, perovskites of the type of nanostructured $\mathrm{BaTiO}_{3}$ and $\mathrm{SrTiO}_{3}$ have been prepared on a large scale by a solid state by reaction of the strontium or barium oxalate with $\mathrm{TiO}_{2}$ in anatase phase at $820^{\circ} \mathrm{C}$ [43].

Supramolecular metal structures have also been used as useful precursors for nanostructured metal oxides. For instance, $\mathrm{Na}_{6}\left[\mathrm{Fe}_{2}(\mu-\mathrm{O})\left(\mu-\mathrm{CO}_{3}\right)-(\text { chnida })_{2}\right] \cdot 13.5 \mathrm{H}_{2} \mathrm{O}(1$; chnida $=\mathrm{N}-[(3$-carboxy-2-oxy-naphthyl)methylene $]$ iminodiacetate $)$, after heating at $1100{ }^{\circ} \mathrm{C}$ affords nanoparticles of $\mathrm{NaFeO}_{2}$ [44].

Additional examples of heterostructures include $\mathrm{Co}_{3} \mathrm{O}_{4} / \mathrm{ZnO}$ composites prepared by thermal treatment of the $\mathrm{Co}_{3} \mathrm{O}_{4} / \mathrm{Zn}(\mathrm{OH})_{2}$ precursor. The as-prepared heterostructure exhibits a high photocatalytic activity toward Rhodamine B dye higher than $\mathrm{ZnO}$ [45]. In a similar way, $\mathrm{Fe}_{3} \mathrm{O}_{4} @ \mathrm{M}$ (where $\mathrm{M}=\mathrm{Au}, \mathrm{Ag}$, and $\mathrm{Au}$-Ag alloy) core-shell nanostructures were synthesized to gram scale in the laboratory conditions by a similar high-temperature solidstate method [46]. The method consists of the thermal treatment of the solid-state mixture of the respective metallic salts with $\mathrm{Fe}_{3} \mathrm{O}_{4}$. The as-obtained $\mathrm{Fe}_{3} \mathrm{O}_{4} @ \mathrm{M}$ nanocomposites exhibited catalytic activity in the obtention of $\mathrm{H}_{2}$ from $\mathrm{NH}_{3} \mathrm{BH}_{3}$ and $\mathrm{NaBH}_{4}$.

Thermal decomposition of organometallic precursors is another usual solid-state route to prepare nanostructured metal oxides. For instance, thermal treatment of the ferrocene carboxaldehide gives $\mathrm{Fe}_{2} \mathrm{O}_{3}$ nanoparticles (hematite phase) with an average size of $5 \mathrm{~nm}$ [47].

Another synthesis strategy arises from the solid-state thermolysis of the metal organic framework (MOFs) [48]: $\mathrm{Zn}(\mathrm{ADA})\left(4,4^{\prime}\right.$-bipy) ${ }_{0.5}, \quad\left[\mathrm{Mn}_{2}(\mathrm{hfbba})_{2}(3-\right.$ mepy) $\left.] \bullet\left(\mathrm{H}_{2} \mathrm{O}\right)\right]$ $\left.\left[\mathrm{Mg}_{3}\left(\mathrm{O}_{2} \mathrm{CH}\right)_{6} \mathrm{I}\left[\mathrm{NH}\left(\mathrm{CH}_{3}\right)_{2}\right]_{0.5}\right], \quad\left[\mathrm{Cd}(\mathrm{ADA})\left(4,4^{\prime} \text {-bipy }\right)_{0.5}\right] \bullet(\mathrm{DMF})\right], \quad\left[\mathrm{Cd}(\mathrm{tdc})(\mathrm{bpy})\left(\mathrm{H}_{2} \mathrm{O}\right)\right]_{\mathrm{n}}$ $\left[\mathrm{Cu}_{3}(\mathrm{TMA})_{2}\left(\mathrm{H}_{2} \mathrm{O}\right)_{3}\right]_{\mathrm{n}}$ and $\left[\mathrm{Co}_{6}(\mathrm{BTC})_{2}(\mathrm{HCOO})_{6}(\mathrm{DMF})_{6}\right]$ affords the nanostructured of $\mathrm{Cu} / \mathrm{CuO}, \mathrm{Co} / \mathrm{Co}_{3} \mathrm{O}_{4}, \mathrm{ZnO}, \mathrm{Mn}_{2} \mathrm{O}_{3}, \mathrm{MgO}, \mathrm{CdS} / \mathrm{CdO}$. These nanoparticles dispersed in a carbon matrix showed promising $\mathrm{H}_{2}$ and $\mathrm{CO}_{2}$ adsorption properties depending on the environment used for the thermolysis of MOFs. 
In a similar manner, additional interesting precursors were the mixture of glucose-ureatransition metal, which, after pyrolysis, gave rise to a series of $2 \mathrm{D}$ porous metal oxides $\mathrm{La}_{0.5} \mathrm{Sr}_{0.5} \mathrm{Co}_{0.8} \mathrm{Fe}_{0.2} \mathrm{O}_{3}, \mathrm{Co}_{3} \mathrm{O}_{4}, \mathrm{NiCo}_{2} \mathrm{O}_{4}$, and $\mathrm{RuO}_{2}$ and $1 \mathrm{D}$ nanowire $\mathrm{Ba}_{0.5} \mathrm{Sr}_{0.5} \mathrm{Co}_{0.8} \mathrm{Fe}_{0.2} \mathrm{O}_{3}$, which were obtained by calcination in the air [49]. The precursors were prepared first, synthesizing the glucose-urea deep eutectic solvent on which the metallic precursors were added. The as-prepared materials exhibit high activity for the electrochemical oxygen evolution.

Finally, polynuclear clusters have also been used in the preparation of $\mathrm{Cr}_{2} \mathrm{O}_{3}$ nanoparticles using a solid-state method starting from direct thermal decomposition of $\left[\mathrm{Cr}_{3} \mathrm{O}\left(\mathrm{CH}_{3} \mathrm{CO}_{2}\right)_{6}\left(\mathrm{H}_{2} \mathrm{O}\right)_{3}\right] \mathrm{NO}_{3} \bullet \mathrm{CH}_{3} \mathrm{COOH}\left(\left[\mathrm{Cr}_{3} \mathrm{O}\right]\right)$ in Ar atmosphere [50]. The nanoplates embedded in carbon show an efficient enhanced electrochemical performance.

Another similar example is the solid-state preparation of $\mathrm{CoFe}_{2} \mathrm{O}_{4} / \mathrm{C}$ from thermal treatment of a heterometallic trinuclear $\left[\mathrm{CoFe} 2 \mathrm{O}\left(\mathrm{CH}_{3} \mathrm{COO}\right)_{6}\left(\mathrm{H}_{2} \mathrm{O}\right)_{3} \cdot 2 \mathrm{H}_{2} \mathrm{O}\right.$ ] [51] complex, showing an average particle size of $50 \mathrm{~nm}$ coated with carbon on the surface.

\subsection{A Novel Solid-State Approximation}

Recently, we have proposed a novel solid-state approximation including two steps [52-67]:

1. The preparation of macromolecular precursors of general formula chitosan•MXn and PS-co-4-PVP.MXn;

2. Pyrolysis of the chitosan·MXn and PS-co-4-PVP•MXn.

The preparation of the macromolecular chitosan॰MXn and PS-co-4-PVP·MXn precursors is performed by a simple coordination reaction using dichloromethane as solvent at room temperature (see Equations (1) and (2)).

$$
\begin{gathered}
M x_{n}+\text { Chitosan } \stackrel{\mathrm{CH}_{2} \mathrm{Cl}_{2}}{\longrightarrow} \text { Chitosan } \cdot M x_{n} \\
M x_{n}+P S-c o-4-P V P \stackrel{\mathrm{CH}_{2} \mathrm{Cl}_{2}}{\longrightarrow} P S-c o-4-P V P \cdot M x_{n}
\end{gathered}
$$

Due to the large coordination site of the polymer (e.g., about 350 for the chitosan $\mathrm{Mw}=61.000)$ and the insolubility of some reactants, the reaction is slow. Ensuring a high percentage of coordination takes about two weeks. However, the insoluble product is easily separable by decantation and dried in vacuum. Products are stable, solid, and with the characteristic color of the precursor metallic salt (e.g., white for $\mathrm{Ti}$, green for $\mathrm{Cr}$ and $\mathrm{Ni}$, etc.).

Pyrolysis of the solid chitosan-MXn and PS-co-4-PVP-MXn precursors under air at $800{ }^{\circ} \mathrm{C}$, usually in a ceramic crucible, affords the nucleation of $\mathrm{M}_{X} \mathrm{O}_{Y}$ metal oxides. The obtained results will be shown in order of the periodic table.

\subsubsection{Transition Metal (First Row)}

Titanium

Titanium dioxide $\left(\mathrm{TiO}_{2}\right)$ is a well-known semiconductor, which can crystallize in eight different polymorphic forms [67], e.g., rutile, anatase, brookite, TiO2-B (bronze). In particular, anatase is known to be a potential solar-driven photocatalyst active for the photodegradation of various dye contaminants [68]. For this study, we selected the following precursors: (Chitosan) $\cdot\left(\mathrm{Cp}_{2} \mathrm{TiCl}_{2}\right)(\mathrm{I}),(\mathrm{PS}-\mathrm{co}-4-\mathrm{PVP}) \cdot\left(\mathrm{Cp}_{2} \mathrm{TiCl}_{2}\right)(\mathrm{II})$, (chitosan) $\left(\mathrm{TiOSO}_{4}\right)(\mathrm{III})$ and $(\mathrm{PS}-\mathrm{co}-4-\mathrm{PVP}) \cdot\left(\mathrm{TiOSO}_{4}\right)(\mathrm{IV})$ and $($ chitosan $) \cdot\left(\mathrm{Ti}(\mathrm{acac})_{2}\right)(\mathrm{V})$ and $(\mathrm{PS}-\mathrm{co}-4-\mathrm{PVP}) \cdot\left(\mathrm{Ti}(\mathrm{acac})_{2}\right)$ (VI). As shown in Table 1, the obtained polymorph of the pyrolytic products depends on the nature of both the polymer and the metallic precursor. It is noteworthy that the chitosan polymer affords a pure rutile phase using $\mathrm{Cp}_{2} \mathrm{TiCl}$ as metallic salt joined to the polymeric chain and pure anatase using $\mathrm{TiO}^{+2}$ joined to the polymeric chain. The polymer PS-co-4-PVP induces a mixture of rutile and anatase phases. A summary of the different products obtained using the different precursors at several temperatures, average sizes, band gaps, and morphologies are displayed in Table 1.

Interestingly, the product from the (TiOSO4)•(Chitosan) precursor at all temperatures affords a pure anatase phase. In contrast, the solution synthesis methods almost always give 
phase mixtures such as anatase/rutile or anatase/brookite. As it will be later discussed in detail, the photocatalytic activity toward blue methylene was tested for $\mathrm{TiO}_{2}$ obtained from all precursors. The best photocatalyst, the anatase obtained from the (chitosan)•( $\left.\mathrm{TiOSO}_{4}\right)$ precursor at $800{ }^{\circ} \mathrm{C}$, achieved a $98 \%$ discoloration rate in only $25 \mathrm{~min}$ when the $\mathrm{pH}$ of the solution was 9.5, improving the efficiency of the standard Degussa P25 photocatalyst without the addition of other phases or dopants.

Table 1. Pyrolysis temperature, phase, particle size, and morphology for the $\mathrm{TiO}_{2}$ obtained from the different precursors at several temperatures.

\begin{tabular}{|c|c|c|c|c|}
\hline \multicolumn{5}{|c|}{${ }^{\mathrm{a}}\left(\mathrm{Cp}_{2} \mathrm{TiCl}_{2}\right) \cdot($ Chiotosan $)$} \\
\hline Temperature $\left({ }^{\circ} \mathrm{C}\right)$ & Phase & Size $(\mathrm{nm})$ & Dispersion (nm) & Morphology \\
\hline 500 & Anatase & 11 & $+/-1$ & Lamellar \\
\hline 600 & Mixture & 13 & $+/-1$ & Lamellar \\
\hline 700 & Mixture & 11 & $+/-1$ & Porous mixture with sheets \\
\hline 800 & Rutile & 24 & $+/-2$ & Highly porous \\
\hline \multicolumn{5}{|c|}{$\left(\mathrm{Cp}_{2} \mathrm{TiCl}_{2}\right) \cdot(\mathrm{PS}-\mathrm{co}-4-\mathrm{PVP})$} \\
\hline Temperature $\left({ }^{\circ} \mathrm{C}\right)$ & Phase & Size (nm) & Dispersion & Morphology \\
\hline 500 & Anatase & 13 & $+/-1$ & Porous and sheets \\
\hline 600 & Anatase & 25 & $+/-9$ & Granular \\
\hline 700 & Anatase & 32 & $+/-3$ & Porous and granular \\
\hline 800 & Mixture & 33 & $+/-2$ & Porous and sheet \\
\hline \multicolumn{5}{|c|}{$\left(\mathrm{TiOSO}_{4}\right) \cdot($ Chitosan $)$} \\
\hline Temperature $\left({ }^{\circ} \mathrm{C}\right)$ & Phase & Size (nm) & Dispersion & Morphology \\
\hline 500 & Anatase & 27 & $+/-1$ & Nanoparticulated microfibers \\
\hline 600 & Anatase & 17 & $+/-5$ & Nanoparticulated microfibers \\
\hline 700 & Anatase & 32 & $+/-2$ & Nanoparticulated microfibers \\
\hline 800 & Anatase & 7 and 32 & $+/-1$ and $+/-2$ & Nanoparticulated microfibers \\
\hline \multicolumn{5}{|c|}{$\left(\mathrm{TiOSO}_{4}\right) \cdot(\mathrm{PS}-\mathrm{co}-4-\mathrm{PVP})$} \\
\hline Temperature $\left({ }^{\circ} \mathrm{C}\right)$ & Phase & Size $(\mathrm{nm})$ & Dispersion & Morphology \\
\hline 500 & Anatase & 11 & $+/-1$ & Irregular porous and microfibers \\
\hline 600 & Anatase & 20 & $+/-1$ & Irregular porous and microfibers \\
\hline 700 & Mixture & 35 & $+/-1$ & Nanoparticulated microfibers \\
\hline 800 & Mixture & 30 & $+/-1$ & Nanoparticulated microfibers \\
\hline \multicolumn{5}{|c|}{$\left(\mathrm{TiO}(\mathrm{acac})_{2}\right) \cdot($ Chitosan $)$} \\
\hline Temperature $\left({ }^{\circ} \mathrm{C}\right)$ & Phase & Size $(\mathrm{nm})$ & Dispersion & Morphology \\
\hline 500 & Anatase & 12 & $+/-1$ & Mainly porous \\
\hline 600 & Anatase & 14 & $+/-1$ & Irregular porous and sheets \\
\hline 700 & Mixture & 25 & $+/-1$ & Irregular porous and sheets \\
\hline 800 & Mixture & 18 & $+/-1$ & Mainly smooth \\
\hline \multicolumn{5}{|c|}{$\left.\left(\mathrm{TiO}(\mathrm{acac})_{2}\right) \cdot \mathrm{PS}-\mathrm{co}-4-\mathrm{PVP}\right)$} \\
\hline Temperature $\left({ }^{\circ} \mathrm{C}\right)$ & Phase & Size $(\mathrm{nm})$ & Dispersion & Morphology \\
\hline 500 & Anatase & 8 & $+/-1$ & Irregular porous \\
\hline 600 & Mixture & 11 & $+/-1$ & Irregular porous \\
\hline 700 & Mixture & 39 & $+/-3$ & Highly porous \\
\hline 800 & Rutile & 62 & $+1-2$ & Irregular porous and sheets \\
\hline
\end{tabular}

a precursor formula.

Vanadium

Owing to its different oxidation states, vanadium has several metal oxides being the most common $\mathrm{VO}, \mathrm{V}_{2} \mathrm{O}_{3}, \mathrm{VO}_{2}$, and $\mathrm{V}_{2} \mathrm{O}_{5}$ [69]. The most common morphology for $\mathrm{V}_{2} \mathrm{O}_{5}$ is the nucleation in lamellar form. Different morphologies as bundles with spindlelike morphologies [70], $\mathrm{V}_{2} \mathrm{O}_{5}$ macro-plates, nanoribbons, nanowires, or nanorods have been reported [71]. For our study, we have selected the chitosan $\bullet\left(\mathrm{VCl}_{3}\right)_{\mathrm{n}}$ and PS-co-4$\mathrm{PVP} \bullet\left(\mathrm{VCl}_{3}\right)_{\mathrm{n}}$ precursors. The same pyrolytic $\mathrm{V}_{2} \mathrm{O}_{5}$ product was obtained for precursors in molar ratios 1:1 and 1:5 [72]. The smallest nanoparticles were obtained for the chitosan precursor in a 1:5 ratio (see Figure 4), where nanoparticles as small as $8 \mathrm{~nm}$ were observed. 


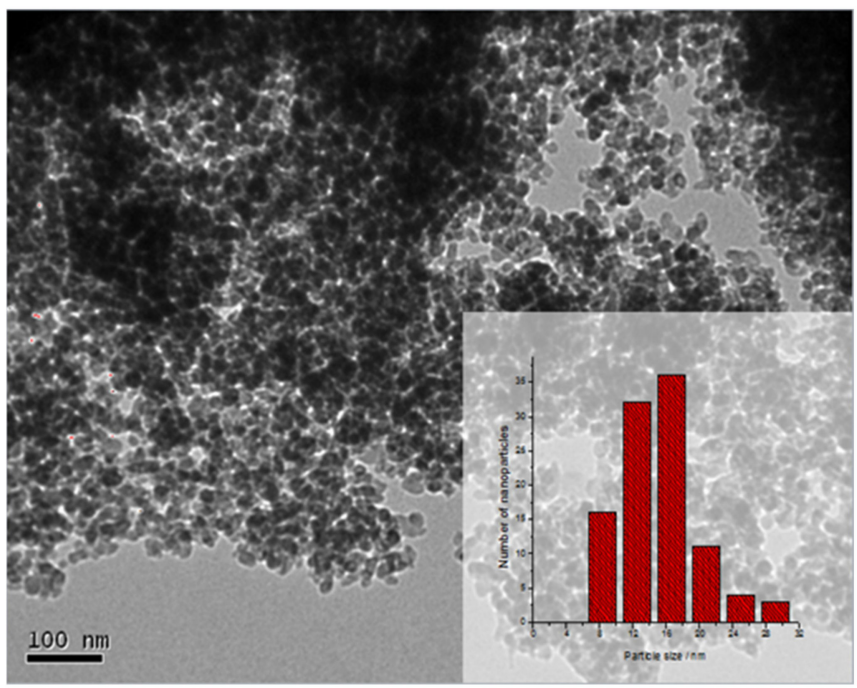

Figure 4. TEM image of the pyrolytic product from $\mathrm{VCl}_{3} \bullet$ chitosan (1:5) and their histogram (inset) adapted from reference [72].

Although several solution methods to prepare nanoparticles of $\mathrm{V}_{2} \mathrm{O}_{5}$ [69-71] have been described, only a few solid-state methods have been reported [73-75]. For example, solid-state thermal decomposition of $\left[\mathrm{NH}_{4} \mathrm{~V}_{3}(\mathrm{OH})_{6}\left(\mathrm{SO}_{4}\right)_{2}\right]$ affords single-crystalline $\mathrm{V}_{2} \mathrm{O}_{5}$ nanoparticles, used as cathode material for lithium-ion batteries [73]. In addition, pyrolysis of the solid $\left[\mathrm{N}_{3} \mathrm{P}_{3}\left(\mathrm{OC}_{6} \mathrm{H}_{5}\right)_{5}\left(\mathrm{OC}_{5} \mathrm{H}_{4} \mathrm{~N} \cdot \mathrm{Cp}_{2} \mathrm{VCl}\right]\left[\mathrm{PF}_{6}\right]\right.$ affords mixtures of $\mathrm{V}_{2} \mathrm{O}_{5} / \mathrm{VO}\left(\mathrm{PO}_{3}\right)_{2}[74]$.

Chromium, Molybdenum, and Tungsten

The most common oxides of the VI group are $\mathrm{Cr}_{2} \mathrm{O}_{3}, \mathrm{MoO}_{3}$ and $\mathrm{WO}_{3}$. These metal oxides can be obtained using the same pyrolitic method, from the respective (chitosan). $\left(\mathrm{CrCl}_{3}\right)_{x}$ and PS-co-4-PVP. $\left(\mathrm{CrCl}_{3}\right)_{\mathrm{x}}, \mathrm{PS}-\mathrm{co}-4-\mathrm{PVP} \bullet\left(\mathrm{MoCl}_{4}\right)_{\mathrm{n}}$ and chitosan $\bullet\left(\mathrm{MoCl}_{4}\right)_{\mathrm{n}}$, and from (chitosan) $\bullet \mathrm{WCl}_{4}$ and PS-co-4-VP. $\mathrm{WCl}_{4}$ precursors [76]. $\mathrm{For} \mathrm{Cr}_{2} \mathrm{O}_{3}$ nanoparticles, the size can be controlled by the metal/polymer ratio decreasing in the order 1:1 $>1: 5>1: 10$.

\section{Manganese}

For this study, we selected the precursors chitosan $\left(\mathrm{MnCl}_{2}\right)_{\mathrm{n}}$ and PS-co-4-PVP. $\left(\mathrm{MnCl}_{2}\right)_{\mathrm{n}}$. XRD analysis clearly shows the presence of $\mathrm{Mn}_{2} \mathrm{O}_{3}$ [77]. Figure 5 shows SEM analysis, indicating the presence of dense grains, some of them fused in 3D arrangement. EDS analysis confirmed the formation of manganese oxide.

Iron

Among the different iron oxides, one of the most common is $\mathrm{Fe}_{2} \mathrm{O}_{3}$ hematite $[78,79]$. For the study with $\mathrm{Fe}$, the following macromolecular complexes were prepared: Chitosan. $\left(\mathrm{FeCl}_{2}\right)_{\mathrm{n}}$, chitosan $\cdot\left(\mathrm{FeCl}_{3}\right)_{\mathrm{n}}$, PS-co-4-PVP. $\left(\mathrm{FeCl}_{2}\right)_{\mathrm{n}}$ and PS-co-4-PVP. $\left(\mathrm{FeCl}_{3}\right)_{\mathrm{n}}$ with molar ratios 1:1, 1:5, and 1:10. A complete study was performed using the following parameters: nature of the polymer, oxidation state of the iron salts, and the metal/polymer ratio. In all the cases, $\mathrm{Fe}_{2} \mathrm{O}_{3}$ (hematite) was obtained. A representative XRD for the pyrolytic product from chitosan. $\left(\mathrm{FeCl}_{3}\right)_{\mathrm{n}}$ 1:1, their SEM and TEM images are shown in Figure 6. XRD data were indexed according to the hematite structure [78-83]. SEM images (Figure $6 \mathrm{~b}-\mathrm{d}$ ) exhibit varied irregular shapes, typical of solid-state methods, but show the correct $\mathrm{Fe}$ and $\mathrm{O}$ content atoms as shown in the EDS analysis (Figure 6e). Consistently, their TEM analysis exhibits agglomerates containing the smallest nanostructures joined in linear dispositions (Figure $6 \mathrm{f}-\mathrm{h}$ ). Chitosan with the $\mathrm{FeCl}_{2}$ salt induces the smallest $\mathrm{Fe}_{2} \mathrm{O}_{3}$ nanoparticle size, while for the PS-PVP polymer, the smallest nanoparticles were 
induced with $\mathrm{FeCl}_{3}$. The 1:1 molar ratio precursor also exhibits the smallest nanoparticles for both polymers.
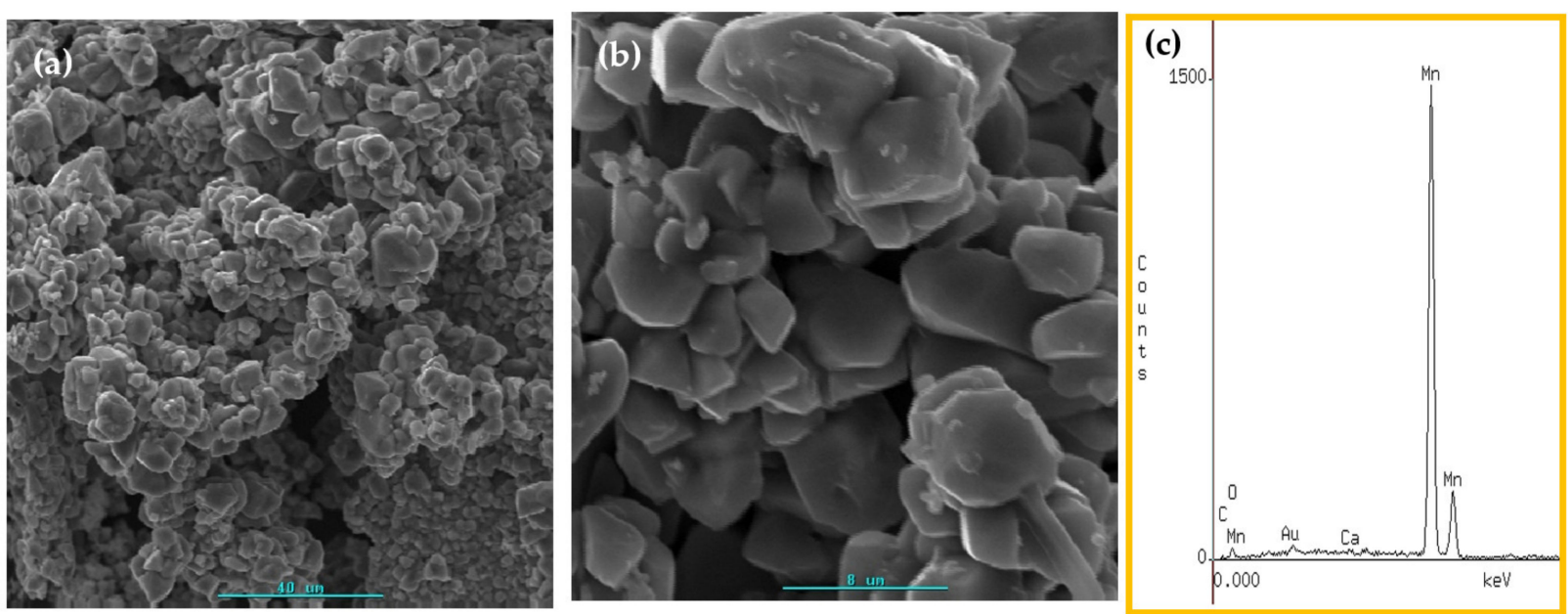

Figure 5. SEM image at two magnification levels (a,b) for $\mathrm{Mn}_{2} \mathrm{O}_{3}$ and their EDS analysis (c).
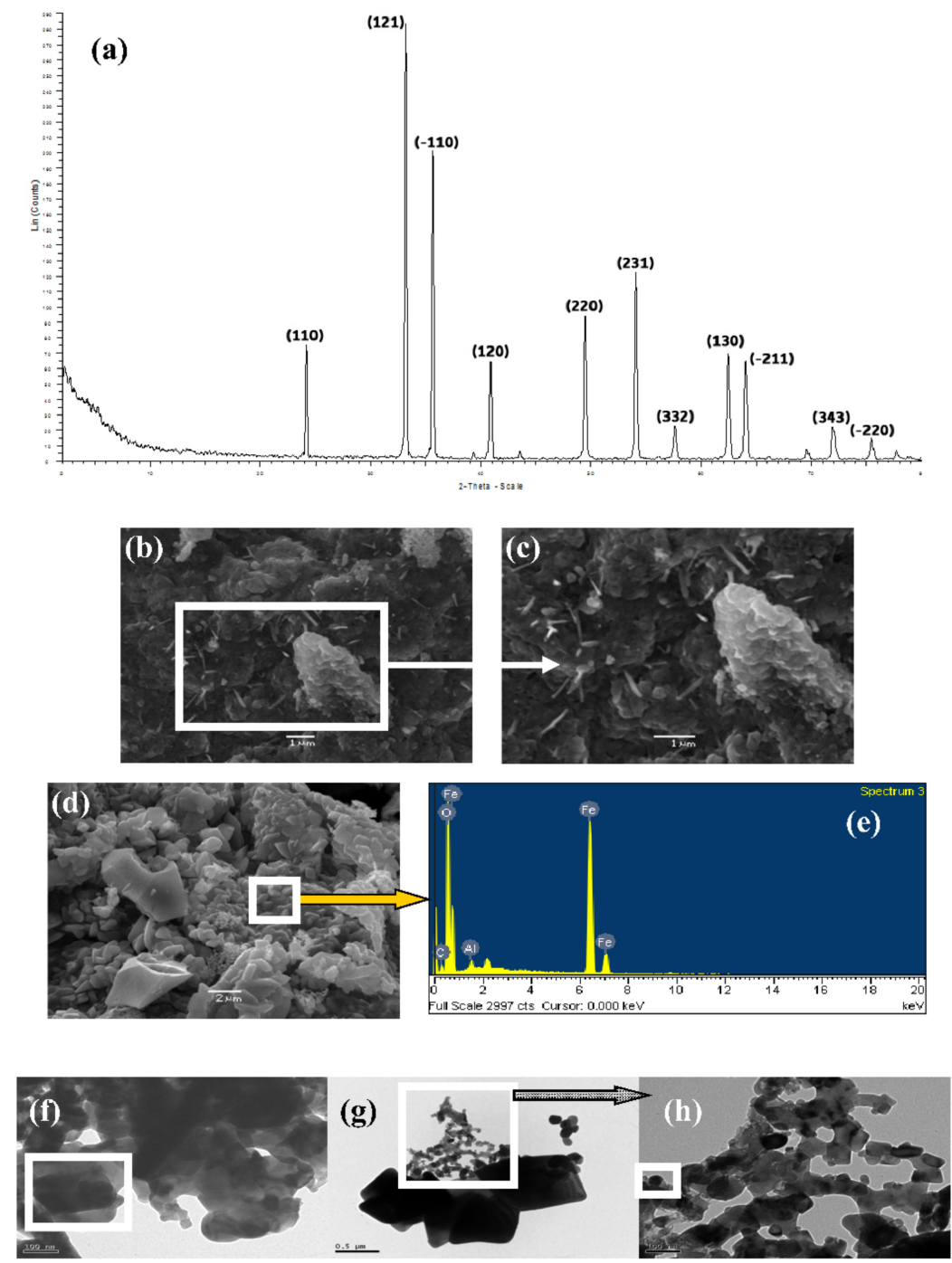

Figure 6. XRD (a), SEM analysis (b-d), EDS (e), and TEM image (f-h) for the pyrolytic product from Chitosan• $\left(\mathrm{FeCl}_{3}\right)_{\mathrm{n}}$ 1:1, hematite- $\mathrm{Fe}_{2} \mathrm{O}_{3}$. 


\section{Cobalt}

Among the different cobalt oxides, $\mathrm{Co}_{3} \mathrm{O}_{4}$ and $\mathrm{CoO}$ [84-89] are the most common, being $\mathrm{Co}_{3} \mathrm{O}_{4}$, for example, used as a supercapacitor electrode material [86]. In this case, chitosan $\left(\mathrm{CoCl}_{2}\right)_{\mathrm{n}}$ and PS-co-4-PVP. $\left(\mathrm{CoCl}_{2}\right)_{\mathrm{n}}$ precursors were selected. XRD analysis shows the presence of $\mathrm{Co}_{3} \mathrm{O}_{4}$ pure phase $[84,85]$, as shown in Figure 7a. SEM images indicate after pyrolysis a dense morphology composed of joined grains to form a 3D arrangement. A similar thermal synthetic approach has been reported [87-89]. As normally found in solid-state methods, morphology with different and varied shapes and sizes are observed. In addition, a solid-state route starting from Co(II) salts has also been reported [84].
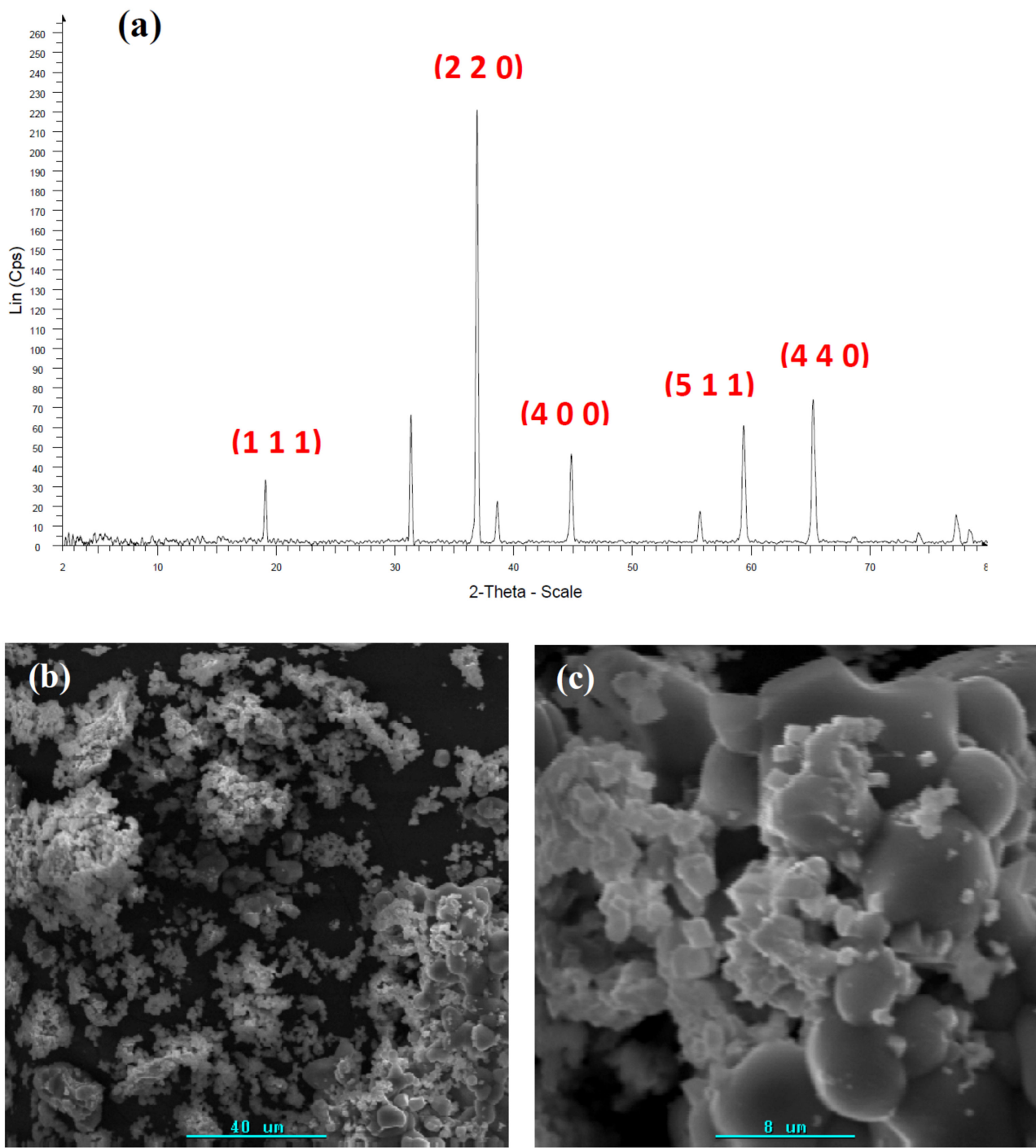

Figure 7. XRD pattern (a) and SEM images $(\mathbf{b}, \mathbf{c})$ for the pyrolytic product from Chitosan $\left(\mathrm{CoCl}_{2}\right)_{\mathrm{n}}$.

Nickel

For this study, we have selected the chitosan $\left(\mathrm{NiCl}_{2}\right)_{\mathrm{n}}$ and PS-co-4-PVP. $\left(\mathrm{NiCl}_{2}\right)_{\mathrm{n}}$ precursors. XRD analysis clearly shows the presence of NiO pure phase. SEM image exhibits a porous morphology, as shown in Figure 8a. EDS analysis corroborates the presence of $\mathrm{Ni}$ and $\mathrm{O}$. For the PS-co-4-PVP. $\left(\mathrm{NiCl}_{2}\right)_{\mathrm{n}}$ precursor, a more porous morphology was observed (Figure 8c). Their EDS analysis also indicates the presence of $\mathrm{Ni}$ and $\mathrm{O}$, see Figure $8 \mathrm{~d}$. 

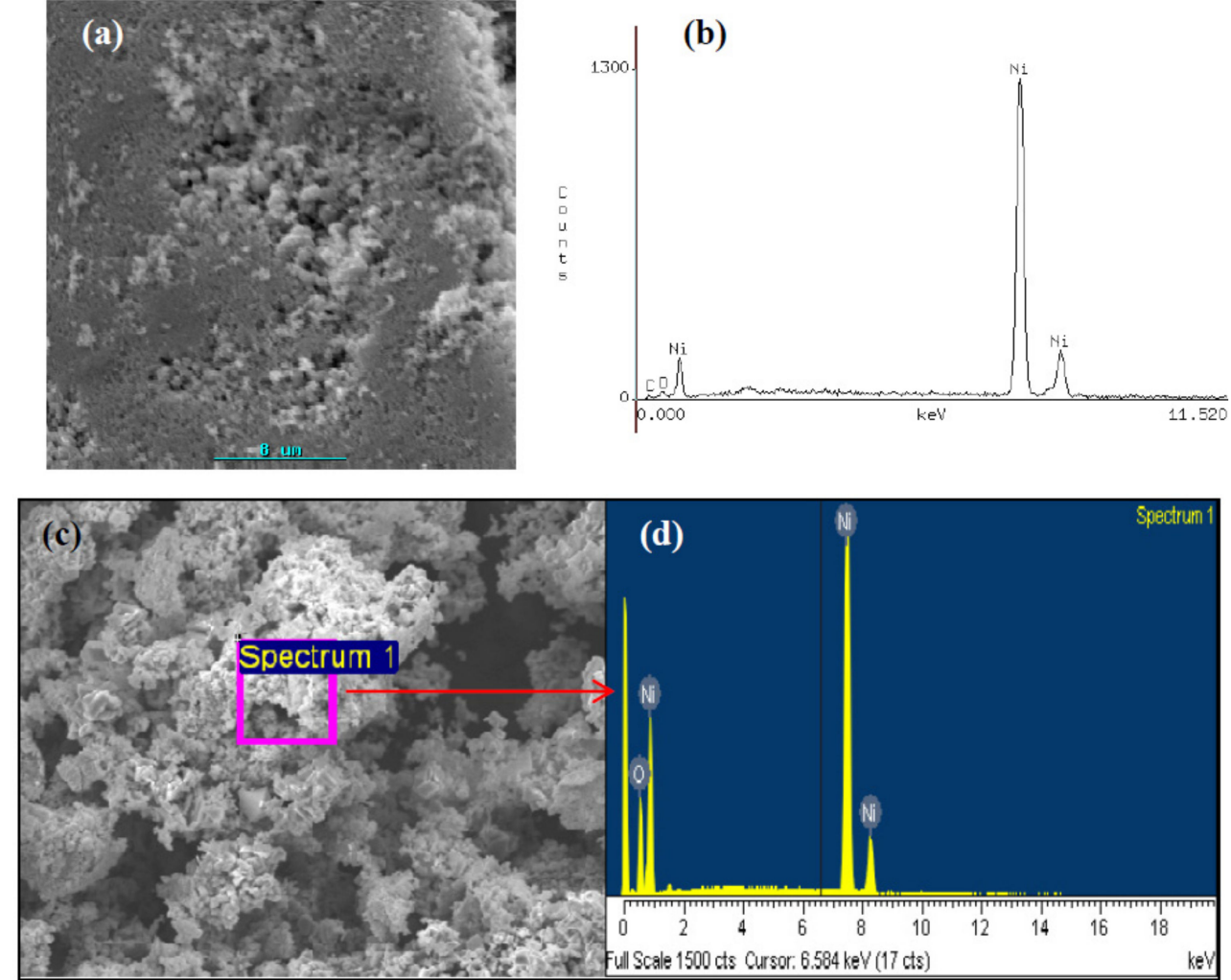

Figure 8. SEM image (a) and EDS analysis (b) from the pyrolytic product from 1:1 Chitosan $\left(\mathrm{NiCl}_{2}\right)_{\mathrm{n}}$ precursor (b) and SEM image (c) and EDS analysis from (d) the 1:1 PS-co-4-PVP. $\left(\mathrm{NiCl}_{2}\right)_{\mathrm{n}}$ precursor.

$\mathrm{NiO}$ is a p-type semiconductor with a band-gap in the range 3.6-4 eV [60]. For their preparation, several solution methods [60] have been reported. In addition, a solid-state thermal method starting from $\left[\mathrm{Ni}(\mathrm{en})_{3}\right]\left[\mathrm{NO}_{3}\right]_{2}[29]$ has been described. The method reported here allowed us to prepare $\mathrm{NiO}$ from inexpensive and commercially available polymer and $\mathrm{Ni}$ salts. Using chitosan $\cdot\left(\mathrm{NiCl}_{2} \cdot \mathrm{H}_{2} \mathrm{O}\right)_{\times}$and PS-co-4-PVP. $\left(\mathrm{NiCl}_{2} \cdot 6 \mathrm{H}_{2} \mathrm{O}\right)_{\times}$precursors [65] and by thermal treatment at $800{ }^{\circ} \mathrm{C}$ under air, pure $\mathrm{NiO}$ phase was obtained. The band-gap of the as-prepared $\mathrm{NiO}$ is $4.15 \mathrm{eV}$ for the one obtained from both Chitosan and PS-co-4-PVP precursors [60]. For the semiconductor metal oxides, their band-gap value dictates their photocatalytic activity [89-92]. In fact, degradation of methylene blue was $71 \%$ and $68 \%$ using $\mathrm{NiO}$ obtained from Chitosan and PS-co-4-PVP precursors [60].

\subsubsection{Noble and Precious Metals}

Noble metals such as $\mathrm{Au}, \mathrm{Pt}$, and $\mathrm{Ag}$ and metal oxides of the precious metal such as Ir, Rh, and Re can also be obtained using the same method. All these metal and metallic nanoparticles can be obtained by pyrolysis of the respective macromolecular chitosan. $\left(\mathrm{ML}_{\mathrm{x}}\right)$ and PS-co-4-PVP. $\left(\mathrm{ML}_{\mathrm{x}}\right)$ precursors using the appropriate metallic salts $\mathrm{ML}_{\mathrm{x}}=\mathrm{AuCl}, \mathrm{AuCl}_{3}$, $\mathrm{AuC}_{6} \mathrm{~F}_{5}, \mathrm{Au}\left(\mathrm{PPh}_{3}\right) \mathrm{Cl}$ for $\mathrm{Au}, \mathrm{Ag}\left(\mathrm{CF}_{3} \mathrm{SO}_{3}\right)_{2}$ for $\mathrm{Ag}, \mathrm{PtCl}_{2}$ for $\mathrm{Pt}, \mathrm{IrCl}_{3}$ for $\mathrm{Ir}, \mathrm{RhCl}_{3}$ for $\mathrm{Rh}$ and $\mathrm{ReCl}_{3}$ for Re.

\section{Gold}

The facile reaction of the $\mathrm{Au}$ metallic salts $=\mathrm{AuCl}, \mathrm{AuCl}_{3}, \mathrm{AuC}_{6} \mathrm{~F}_{5}, \mathrm{Au}\left(\mathrm{PPh}_{3}\right) \mathrm{Cl}$ with the PS-4-co-PVP polymer leads to the luminescent macromolecular complexes PS-4-co$\mathrm{PVP} \cdot \mathrm{AuCl}_{3}, \mathrm{PS}-4-\mathrm{co}-\mathrm{PVP} \cdot \mathrm{AuCl}$, PS-4-co-PVP. $\mathrm{AuC}_{6} \mathrm{~F}_{5}$, and PS-4-co-PVP. $\mathrm{Au}\left(\mathrm{PPh}_{3}\right) \mathrm{Cl}$. The observed luminescence for PS-4-co-PVP. $\mathrm{AuC}_{6} \mathrm{~F}_{5}$ with a maximum around $550 \mathrm{~nm}$, as shown in Figure 9, arises probably from the $\mathrm{Au}(\mathrm{I})-\mathrm{Au}(\mathrm{I})$ interactions [93]. Interestingly, the macromolecular complex PS-4-co-PVP• $\left(\mathrm{AuCl}_{3}\right)_{\mathrm{n}}$ does not present this luminescent behavior. 


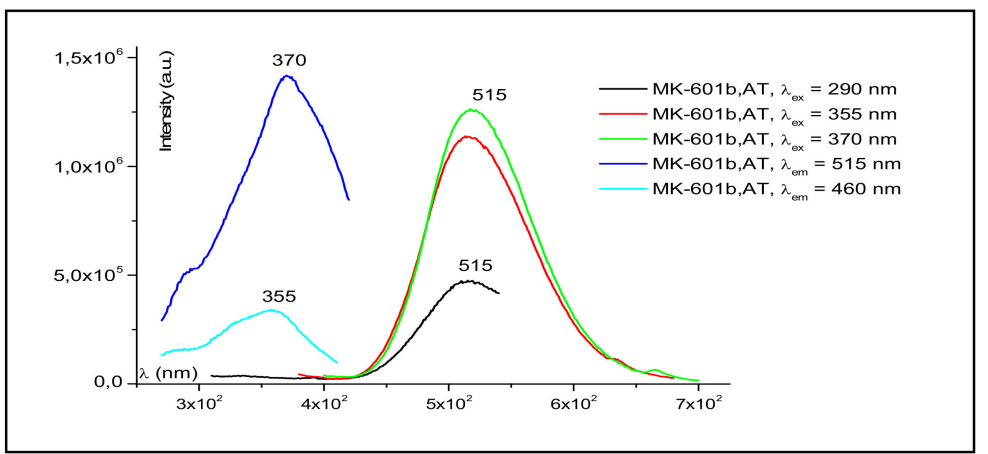

Figure 9. Luminescence spectrum of PS-4-co-PVP. $\mathrm{AuC}_{6} \mathrm{~F}_{5}$ at several excitation wavelengths.

The pyrolysis of all these macromolecular precursors affords metallic $\mathrm{Au}^{\circ}$ foams with pore size depending on the nature of the Au salt joined to the polymer chain [94] (Figure 10).
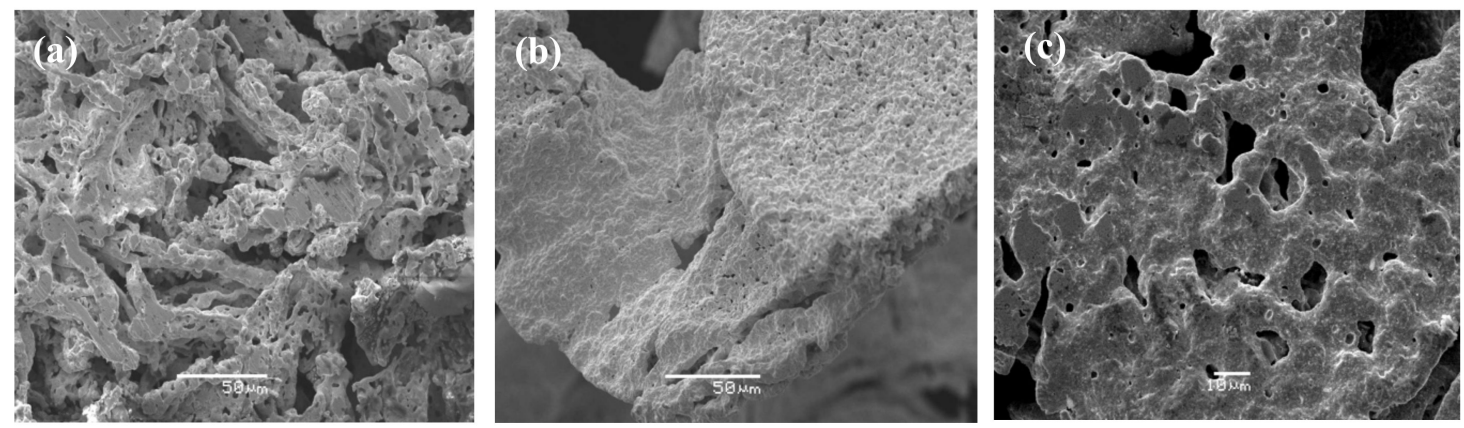

Figure 10. SEM images for the different $\left(\mathrm{AuX} \mathrm{X}_{\mathrm{n}}\right)_{\mathrm{n}}$ samples: (a) $\mathrm{AuCl},(\mathbf{b}) \mathrm{AuCl}_{3}$, and (c) $\mathrm{Au}\left(\mathrm{C}_{6} \mathrm{~F}_{5}\right)$.

Metallic sponges (or foams) of macroporous metals have attracted great attention due to their unusual and peculiar properties such as mechanical strength and stiffness [95]. These materials can be prepared by several solution methods as dealloying of $\mathrm{M} / \mathrm{M}^{\prime}$ alloys and by forming a metal organic composite and eliminating the organic part by dissolution or calcination. However, no solid-state approximations have been reported. The method described here could be a novel and reliable way to prepare metallic foams from different noble metals.

Silver

Several solution methods for preparing $\mathrm{Ag}^{\circ}$ nanoparticles have been reported but relatively scarce from solid-state methods [96-98]. For $\mathrm{Ag}^{\circ}$ containing precursors as $\mathrm{Ag}\left(\mathrm{CF}_{3} \mathrm{SO}_{3}\right) \cdot$ Chitosan, $\mathrm{Ag}$ was obtained as shown in the XRD pattern [94]. Their morphology indicates a foam-like shape. Finally, EDS analysis confirmed the presence of Ag as a pure single phase.

\section{Platinum}

Nanostructured Pt nanoparticles are very important, for example, in the catalysis of fuel cells, sensors, and the petroleum and automotive industries due to their high catalytic activity and stability [98].

Pt nanoparticles were obtained from the chitosan $\cdot\left(\mathrm{PtCl}_{2}\right)_{\mathrm{n}}$ and PS-co-4-PVP. $\left(\mathrm{PtCl}_{2}\right)_{\mathrm{n}}$ precursors [99]. As shown in Figure 11, the obtained Pt nanoparticles exhibit varied shapes and sizes, some of them with the typical truncated octahedron [99,100]. This also can be viewed as an image of a cubohedral structure viewed along the [101] zone axis. 

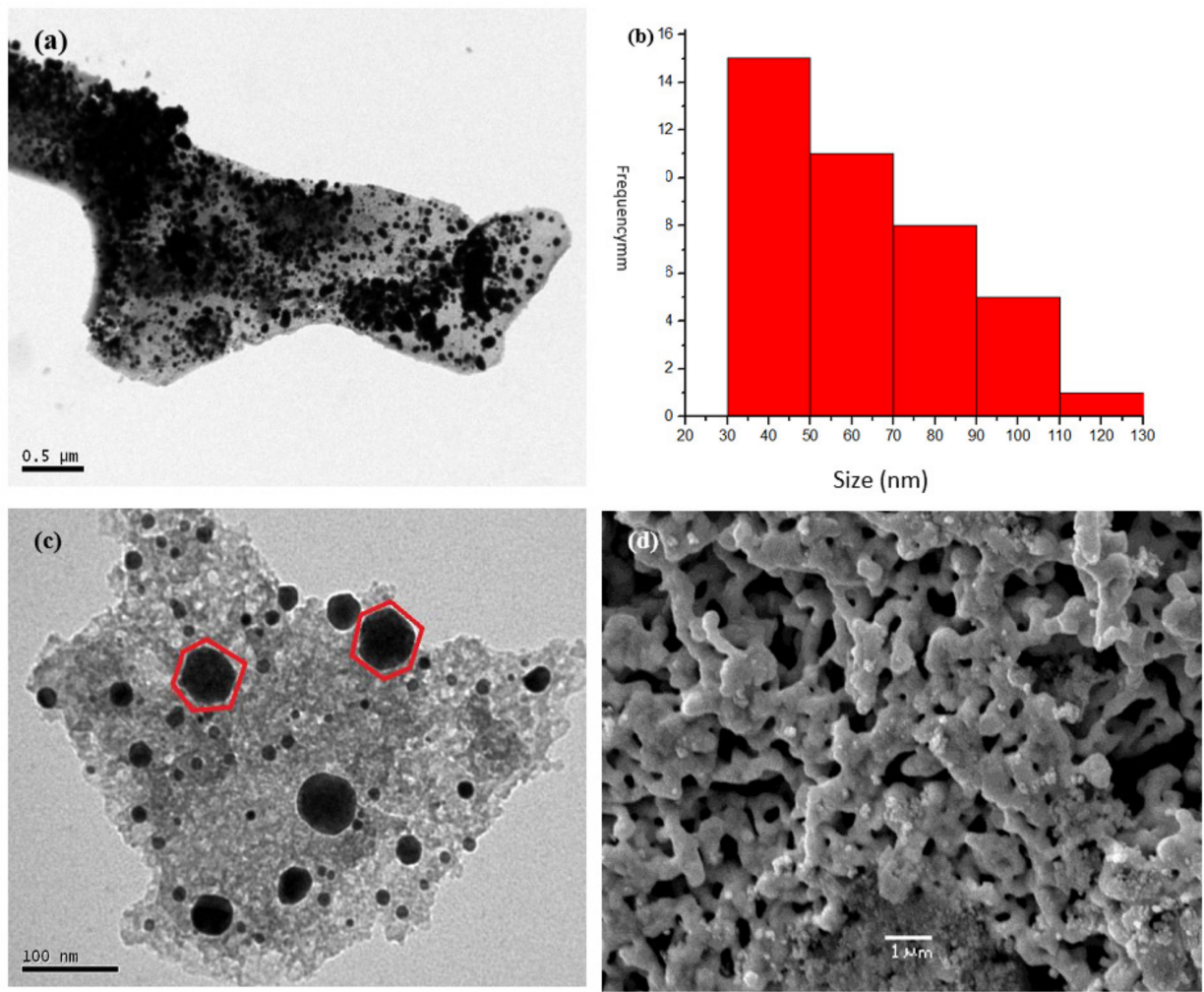

Figure 11. TEM image (a), particle size histogram, (b), TEM image in a magnified area (c), and an SEM image (d) for the pyrolytic products from the PS-co-4-PVP. $\left(\mathrm{PtCl}_{2}\right)_{n}$ precursors. Adapted from reference [99].

The smallest particle size $(6 \mathrm{~nm})$ was obtained from the pyrolytic product from the chitosan. $\left(\mathrm{PtCl}_{2}\right)_{\mathrm{n}}$ precursor in a 1:1 molar ratio. In spite of numerous preparation methods of Pt nanoparticles reported [101-103], few solid-state methods have appeared.

Another interesting aspect is the "foam-like" morphology observed for pyrolytic products from the precursors 1:5 ratio PS-co-4-PVP. $\left(\mathrm{PtCl}_{2}\right)_{\mathrm{n}}$. Few metallic Pt sponges materials have been reported, being this the only solid-state route for this type of material [95].

\section{Iridium}

Among the metals of the periodic table, the precious as Ir is one of the most catalytically active [104]. Their activity is hugely enhanced at the nano level [105-107]. This metal, as well as its metal oxides, exhibits a high catalytic activity $[104,106]$. Although isolated solution preparation methods for nanostructured Ir oxides are well documented [108-114], no solid-state general methods to prepare $\mathrm{IrO}_{2}$ nanostructured have been shown. $\mathrm{IrO}_{2}$ is generally prepared from an Ir salt. The relative fraction of $\mathrm{IrO}_{2} / \mathrm{Ir}$ depends on the temperature, producing $\operatorname{Ir}_{2} \mathrm{O}_{3}$ at temperatures between 250 and $400{ }^{\circ} \mathrm{C}$, and then obtaining pure $\mathrm{IrO}_{2}$ at temperatures above $600^{\circ} \mathrm{C}$ [108-114]. Using our method, we have obtained a unique nanostructured phase of $\mathrm{IrO}_{2}$ [63]. The $\mathrm{IrO}_{2}$ nanoparticles were prepared by thermal treatment of the macromolecular chitosan-( $\left(\mathrm{IrCl}_{3}\right) \mathrm{X}$ and PSP-4-PVP. $\left(\mathrm{IrCl}_{3}\right) \mathrm{x}$ precursors. The nature of the polymeric precursor is acting as a solid-state template and influences the size of the iridium dioxide but not significantly the morphology, and the obtained $\mathrm{IrO}_{2}$ nanoparticles are about $15 \mathrm{~nm}$.

Rhodium

Rhodium is another catalytically active precious metal [115]. Their activity is also hugely enhanced at the nano level $[115,116]$. Among these various noble metals, rhodium plays an important role in various catalytic applications $[117,118]$. However, the catalytic mechanism of rhodium-containing materials is still elusive. Recent investigations suggest 
that the active centers could be rhodium oxide rather than rhodium [118-122]. The most common rhodium oxides are $\mathrm{Rh}_{2} \mathrm{O}_{3}$ and $\mathrm{RhO}_{2}$. Although these rhodium oxides have a wide range of applications in catalysis, scarce preparation methods of nanostructured $\mathrm{Rh}_{2} \mathrm{O}_{3}$ and $\mathrm{RhO}_{2}$ have been reported, and their morphological and size control is vaguely known [7-9,118-122].

A nanostructured $\mathrm{Rh} / \mathrm{RhO}_{2}$ mixture was easily obtained by thermal treatment of the macromolecular chitosan. $\left(\mathrm{RhCl}_{3}\right)_{\mathrm{x}}$ precursor, while the pure $\mathrm{Rh}_{2} \mathrm{O}_{3}$ was obtained from pyrolysis of the PSP-4-PVP. $\left(\mathrm{RhCl}_{3}\right)_{\mathrm{X}}$ precursor [64]. The nature of the polymeric precursor acting as a solid-state template does not significantly influence the morphology of the Rh and their metal oxide. The average size of the as-obtained products is in the range of $20 \mathrm{~nm}$.

\subsubsection{Representative Metals}

$\mathrm{SnO}_{2}$ and $\mathrm{ZnO}$ are two of the most used materials in sensors [123-125]. $\mathrm{SnO}_{2}$ is a wide band-gap n-type semiconductor with great importance in several technological applications such as gas sensing, Li-ion batteries, and solar cells [124]. As a sensor, its main application is in $\mathrm{H}_{2}$ and $\mathrm{CO}$ detection. In addition, nanostructured $\mathrm{ZnO}$ is one of the most promising nanomaterials for sensors due to its biocompatibility, chemical and photochemical stability, high specific surface area, optical transparency, electrochemical activity and high electron mobility. ZnO has been employed for the detection of biological molecules [126].

$\mathrm{SnO}_{2}$ and $\mathrm{ZnO}$ were prepared by pyrolysis of macromolecular complexes: PS-co-4$\mathrm{PVP} \cdot\left(\mathrm{SnCl}_{2}\right)_{\mathrm{n}}$ and PS-co-4-PVP. $\left(\mathrm{ZnCl}_{2}\right)_{\mathrm{n}}$ in several molar ratios under air at $800{ }^{\circ} \mathrm{C}[53$ ]. For $\mathrm{ZnO}$ agglomerates, the respective hexagonal and cubic structures were observed with typical sizes of 30-50 $\mathrm{nm}$ for a precursor mixture ratio of 1:1.

Figure 12 shows, for instance, the SEM image for the pyrolytic precursor from PS-co-4$\mathrm{PV} \cdot\left(\mathrm{ZnCl}_{2}\right)_{\mathrm{n}}$ in 1:5 ratio where zones with "metallic foams" as well as cubic morphologies were observed.

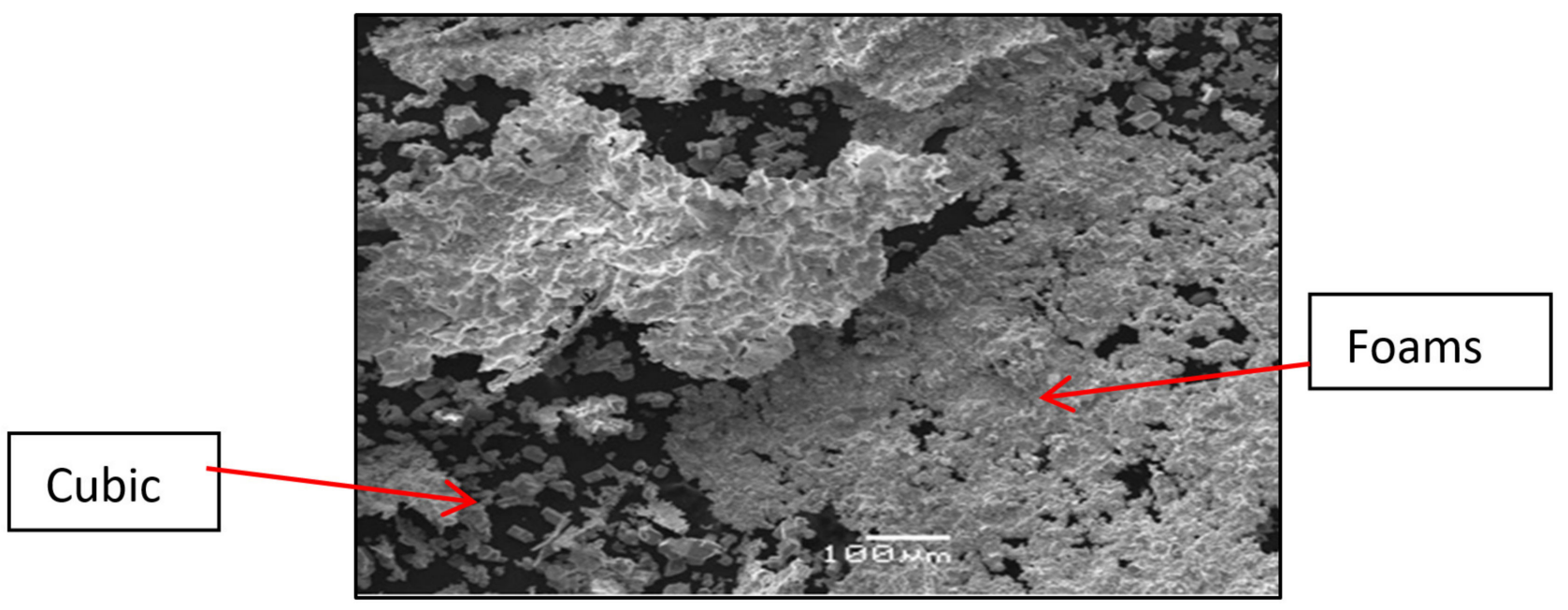

Figure 12. SEM image for the pyrolytic precursor from PS-co-4-PVP. $\left(\mathrm{ZnCl}_{2}\right)_{\mathrm{n}}$ in ratio 1:5. Adapted from reference [53].

For the $\mathrm{SnO}_{2}$ semiconductor, the oxide was prepared from the PS-co-4-PVP. $\left(\mathrm{SnCl}_{2}\right)_{\mathrm{n}}$ precursor. The nanostructured $\mathrm{SnO}_{2}$ exhibits morphologies and particle sizes depending on the molar ratio of the $\mathrm{SnCl}_{2}$ :PS-CO-4-PVP. When a larger weight fraction of the inorganic salt is used in the precursor (1:1), larger crystalline crystals are found for each oxide. As shown in Figure 13, the SEM image indicates an irregular morphology, including some "foam" shapes. EDS analysis confirmed the presence of Sn and O atoms. 


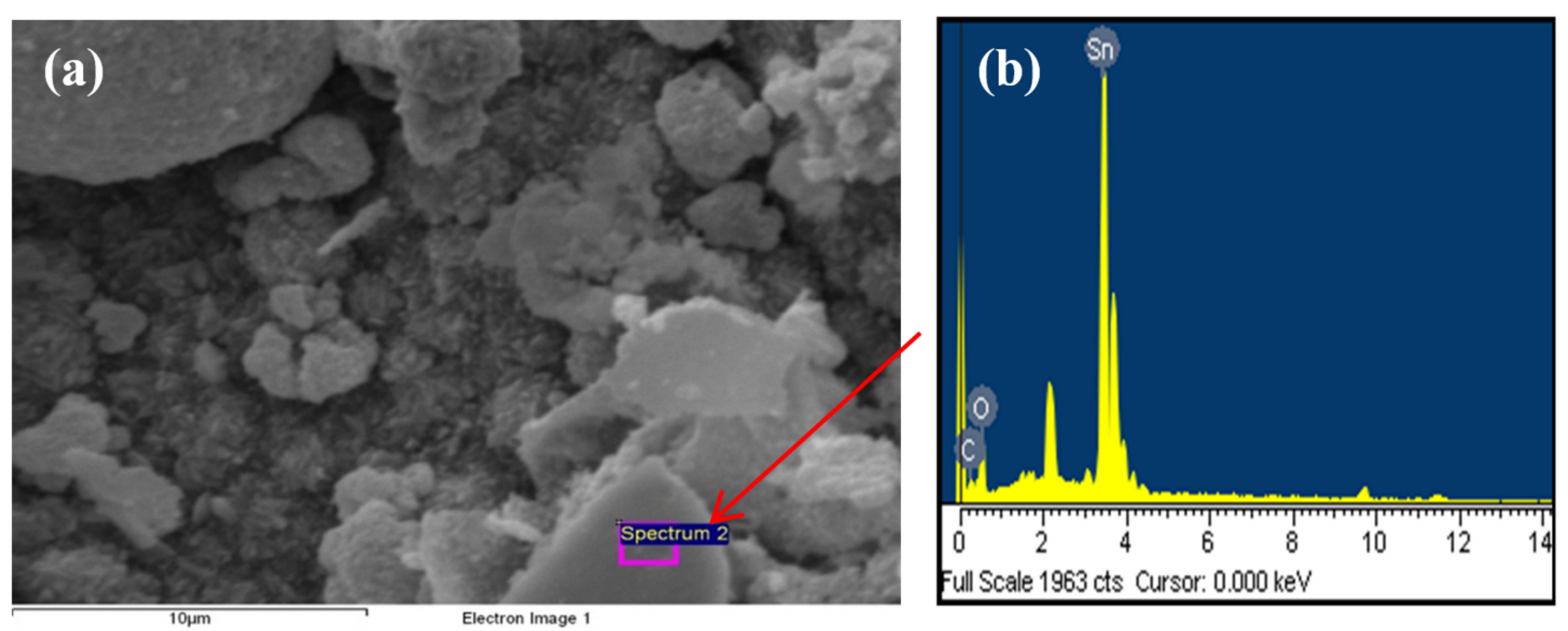

Figure 13. SEM image (a) and EDS analysis (b) of the $\mathrm{SnO}_{2}$ obtained from PS-co-4-PVP. $\left(\mathrm{SnCl}_{2}\right)_{\mathrm{n}}$ precursor.

Nanostructured $\mathrm{ZnO}$ was also obtained from the macromolecular chitosan $\cdot\left(\mathrm{ZnCl}_{2}\right)$ and PSP-co-4-PVP. $\left(\mathrm{SnCl}_{2}\right)_{\mathrm{n}}$ complexes [29].

\subsubsection{Rare Metals}

Rare earth compounds have drawn attention due to their unique properties and promising application in, for example, UV-shielding, luminescent display, optical communications, biochemical probes, and medical diagnostic [127-130]. Among the rare earth compounds, metal oxides showed a variety of attractive features for applications in several fields of technology. However, few general preparation methods have been reported [131]. Using the above-described method, we can obtain rare earth oxide nanostructured compounds, although in some cases, the lanthanum oxyhalides were also obtained instead of the expected oxide $\mathrm{Ln}_{2} \mathrm{O}_{3}$. $\mathrm{LnOX}(\mathrm{Ln}=$ lanthanide element, $\mathrm{X}=$ halide) compounds have unique and excellent characteristics in electrical, magnetic, optical and luminescent properties [132,133].

Pyrolysis products of the macromolecular PSP-co-4-PV $\left(\mathrm{ML}_{n}\right)_{n}$ and chitosan $\bullet\left(\mathrm{ML}_{n}\right)_{\mathrm{n}}$ $\left(\mathrm{M}=\right.$ lanthanide metal) complexes afford products of composition $\mathrm{M}_{2} \mathrm{O}_{3}$ or $\mathrm{MOCl}$ depending on the nature of the $\mathrm{ML}_{n}$ salt. When $\mathrm{ML}_{n}$ is $\mathrm{MCl}_{3}$, the product is the oxychloride $\mathrm{MOCl}$, while when $\mathrm{ML}_{\mathrm{n}}$ is $\mathrm{M}\left(\mathrm{NO}_{3}\right)_{3}$ or $\mathrm{M}_{2}\left(\mathrm{SO}_{4}\right)_{2}$, the respective $\mathrm{M}_{2} \mathrm{O}_{3}$ is obtained. For instance, pyrolysis of the macromolecular PSP-co-4-PVP. $\left(\mathrm{Ce}\left(\mathrm{NO}_{3}\right)_{3}\right)_{\mathrm{n}}$ precursor gives rise to $\mathrm{CeO}_{2}$. The different obtained materials were identified by XRD. TEM shows the typical arrangements of nanoparticles somewhat agglomerated, as is displayed in Figure 14a. HRTEM images in Figure $14 \mathrm{~b}$ confirm that the method allowed agglomerates of single-crystal nanoparticles of $\mathrm{CeO}_{2}$.

On the other hand, pyrolysis of chitosan $\bullet \mathrm{NdCl}_{3}$ and PSP-Co-4-PVP. $\mathrm{NdCl}_{3}$ give rise to $\mathrm{NdOCl}$ in both cases, as confirmed by XRD [60]. In some cases, a mixture with $\mathrm{Nd}_{2} \mathrm{O}_{3}$ oxide was also observed. SEM image exhibits a 3-D metallic foam morphology for the pyrolytic products from chitosan $\cdot \mathrm{NdCl}_{3}$. EDS confirmed the presence of $\mathrm{Nd}, \mathrm{O}$, and $\mathrm{Cl}$ in agreement with the proposed formula. TEM image displayed irregular shapes with varied sizes [60], as shown in Figure 15c. 

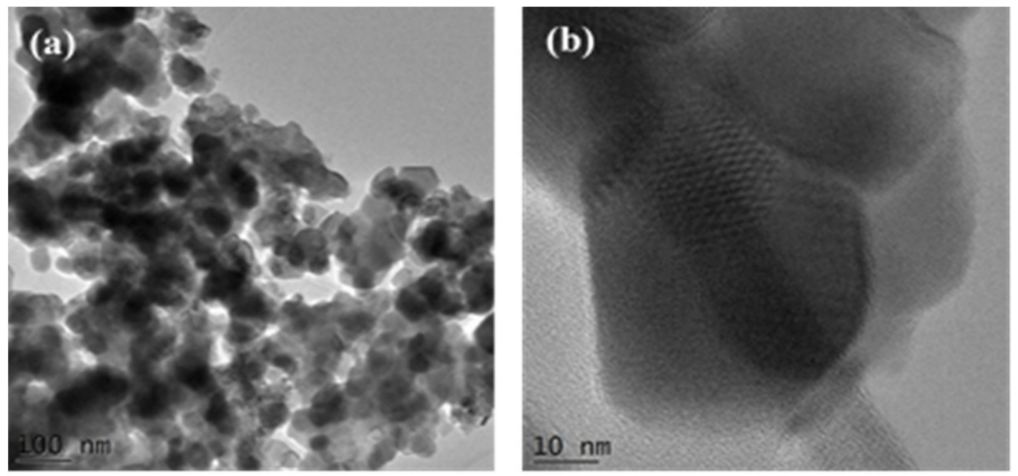

Figure 14. TEM image (a) and HRTEM (b) image of pyrolytic product from the precursor PSP-co-4PVP. $\left(\mathrm{Ce}\left(\mathrm{NO}_{3}\right)_{3}\right)_{\mathrm{n}}$.

It is remarkable that $\mathrm{Eu}^{+3}$ doped $\mathrm{NdOCl} / \mathrm{Eu}_{2} \mathrm{O}_{3}$ materials obtained from pyrolysis of chitosan $\bullet \mathrm{NdCl}_{3} / \mathrm{EuCl}_{3}$ exhibit a 3D metallic foam structure (Figure 15) [57]. Interestingly, we observed the presence of $\mathrm{Eu}$, in addition to the expected $\mathrm{Nd}, \mathrm{O}$, and $\mathrm{Cl}$ atoms, in the respective EDS (Figure 15b). The solid-state luminescence of this system shows the main emission line around $566 \mathrm{~nm}$ assigned to the ${ }^{5} \mathrm{D}_{0} \rightarrow{ }^{2} \mathrm{~F}_{2}$ transition [57].
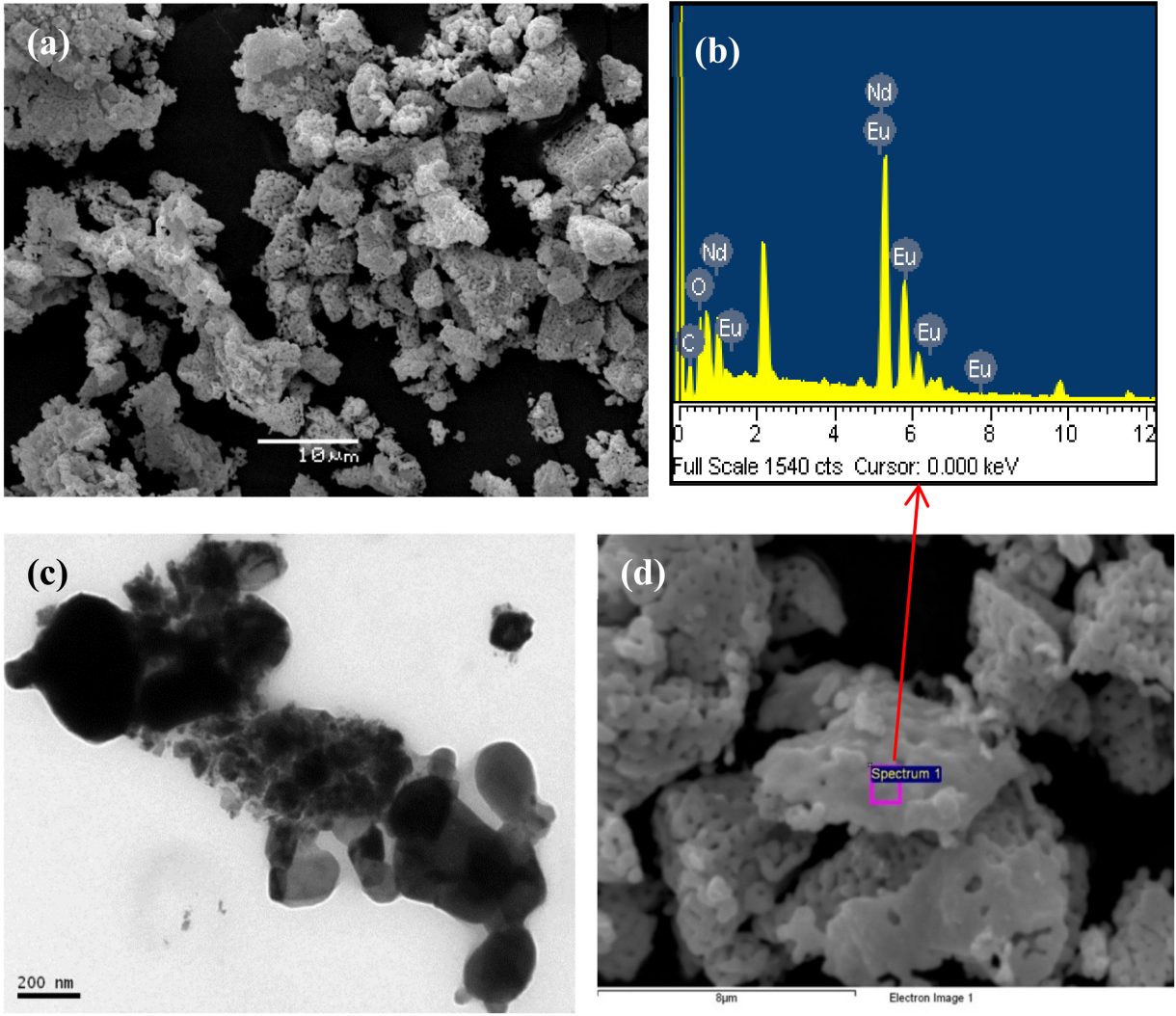

Figure 15. SEM (a,d), EDS (b), and TEM image (c) of the pyrolytic products from $\mathrm{Eu}^{3+}$ doped, Chitosan $\cdot \mathrm{NdCl}_{3}$.

\subsubsection{Actinides}

Among the different actinide oxides, thoria is an important and promising material used as a ceramic catalyst sensor in solid electrolytes, catalysis, and optical materials, as well as in the traditional nuclear industry [134-138]. In spite of this, few papers related to the preparation and properties of nanostructured $\mathrm{ThO}_{2}$ have appeared. We have prepared nanostructured $\mathrm{ThO}_{2}$ from the chitosan. Th $\left(\mathrm{NO}_{3}\right)_{4}$ and PS-co-4-PVP.Th $\left(\mathrm{NO}_{3}\right)_{4}$ 
precursors [66]. The morphology and the average size of the as-obtained $\mathrm{ThO}_{2}$ depend on the Chitosan and PS-co-4-PVP polymer forming the precursor. A total of 50 and $40 \mathrm{~nm}$ average sizes were observed from the Chitosan and PS-co-4-PVP polymer precursors. The as-obtained thoria exhibits the expected luminescence with a dependence on their intensity emission maxima and the nature of the precursor polymer.

\section{Incorporation of Metallic and Metal Oxides into Solid Matrix}

Various practical applications, for instance, catalysis, involving solid-state devices are formed by nanoparticles and/or nanostructured inside a solid matrix as $\mathrm{SiO}_{2}, \mathrm{TiO}_{2}$, $\mathrm{Al}_{2} \mathrm{O}_{3}$, glasses, and so on $[139,140]$. We have designed a solid-state methodology to prepare different composites: $\mathrm{M} / \mathrm{M}^{\prime}{ }_{\mathrm{x}} \mathrm{O}_{\mathrm{y}}^{\prime}$ and $\mathrm{M}_{\mathrm{x}} \mathrm{O}_{\mathrm{y}} / \mathrm{M}^{\prime}{ }_{\mathrm{x}} \mathrm{O}^{\prime}{ }_{\mathrm{y}}$ with $\mathrm{M}^{\prime}{ }_{\mathrm{x}} \mathrm{O}^{\prime}{ }_{\mathrm{y}}$ solid matrix, i.e., $\mathrm{SiO}_{2}$, $\mathrm{TiO}_{2}, \mathrm{Al}_{2} \mathrm{O}_{3}$, under air thermal treatment of the chitosan $\cdot \mathrm{MLn} / / \mathrm{M}_{\mathrm{x}}^{\prime} \mathrm{O}_{\mathrm{y}}^{\prime}$ and PS-co-4PVP.MLn/ $/ \mathrm{M}^{\prime}{ }_{\mathrm{x}} \mathrm{O}^{\prime}$ precursors. Using this synthetic methodology, we have been able to prepare several metallic nanoparticles as well as metal oxides included in solid matrices.

As known in catalysis, the inclusion of $\mathrm{M}^{\circ}$, as well as $\mathrm{MxOy}$ inside solid matrices, induces stability of the catalytic material as well as a greater surface area of the catalyst within the solid matrix $[139,140] . \mathrm{Au}^{\circ}$ and the bimetallic $\mathrm{Au}^{\circ} / \mathrm{Ag}^{\circ}$ were incorporated in silica to give $\mathrm{Au}^{\circ} / / \mathrm{SiO}_{2}$ [94] and $\mathrm{Au}^{\circ} / \mathrm{Ag}^{\circ} / / \mathrm{SiO}_{2}$ [56].

Nanoparticles of about $5 \mathrm{~nm}$ can be observed in Figure 16. The distribution of the $\mathrm{Au}^{\circ}$ nanoparticles inside silica was examined by SEM-EDS mapping, as seen in Figure 17.

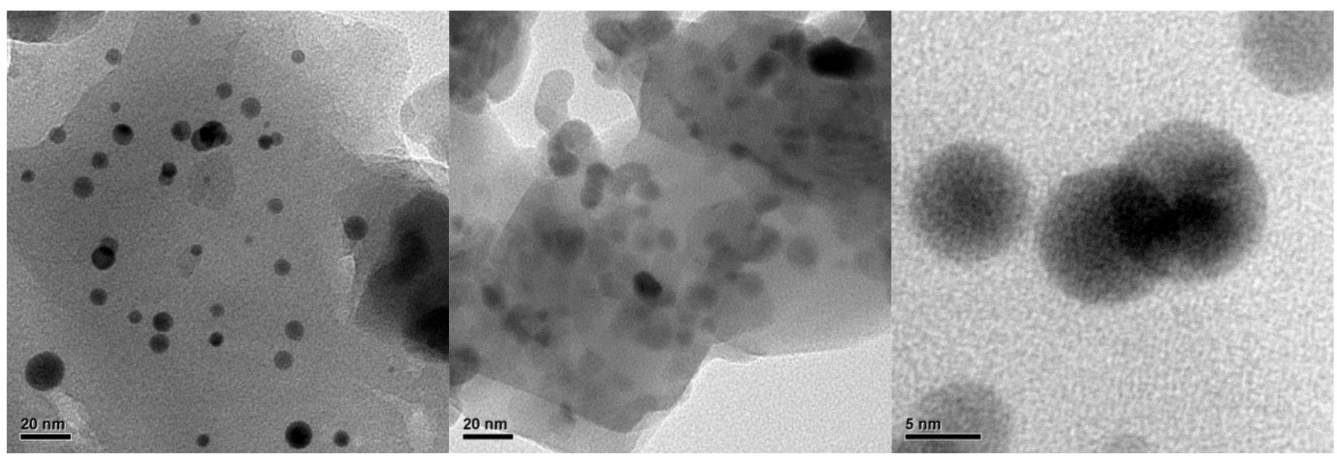

Figure 16. HRTEM images of Au nanoparticles inside $\mathrm{SiO}_{2}$ from $(\mathrm{PS}-\mathrm{co}-4-\mathrm{PVP}) \bullet\left(\mathrm{AuCl}_{3}\right)_{\mathrm{n}} \bullet\left(\mathrm{SiO}_{2}\right)_{\mathrm{n}}$ precursor. Adapted from reference [94].

Si $K \alpha 1$

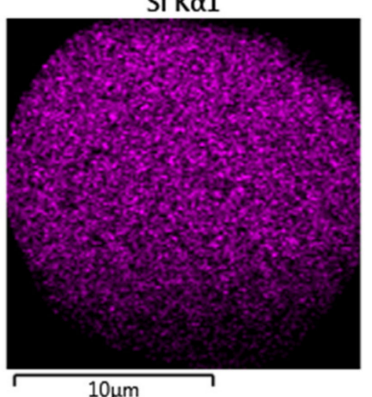

$\mathrm{OK} \alpha 1$

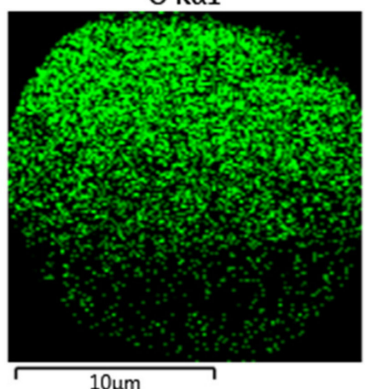

$\mathrm{Au} \mathrm{M} \alpha 1$

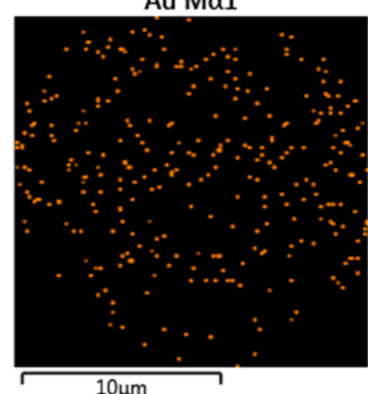

Figure 17. EDS mapping by elements of the $\mathrm{Au} / \mathrm{SiO}_{2}$ nanocomposite from the precursor Chitosan $\bullet\left(\mathrm{AuCl}_{3}\right)_{\mathrm{n}} \cdot\left(\mathrm{SiO}_{2}\right)_{\mathrm{n}}$ in 1:1 molar ratio polymer/metal. Adapted from reference [94].

From this figure, regular distribution of the $\mathrm{Au}^{\circ}$ nanoparticles inside silica was observed. In addition, the inclusion of the bimetallic $\mathrm{Au}^{\circ} / \mathrm{Ag}^{\circ}$ nanoparticles was performed by pyrolysis under air at $800{ }^{\circ} \mathrm{C}$ of the PSP-4-PVP• $\left(\mathrm{AuCl}_{3} / \mathrm{AgSO}_{3} \mathrm{CF}_{3}\right)_{\mathrm{n}} \cdot \mathrm{SiO}_{2}$ and chitosan $\cdot\left(\mathrm{AuCl}_{3} / \mathrm{AgSO}_{3} \mathrm{CF}_{3}\right)_{\mathrm{n}} \cdot \mathrm{SiO}_{2}$ precursors. The relative distribution of the $\mathrm{Au} / \mathrm{Ag}$ bimetallic nanoparticles inside silica was observed by the EDS mapping shown in Figure 18. 

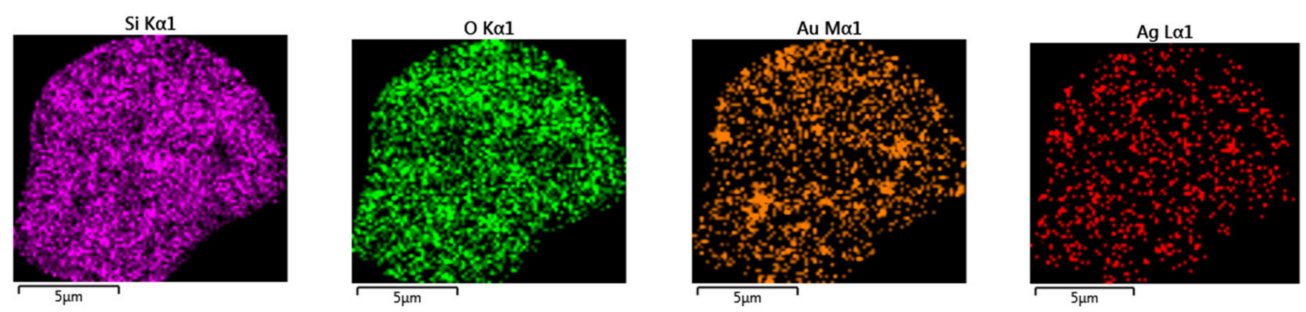

Figure 18. EDS mapping for the $\mathrm{Au} / \mathrm{Ag} / / \mathrm{SiO}_{2}$ composite from the macromolecular Chitosan $\cdot\left(\mathrm{AuCl}_{3} / \mathrm{AgSO}_{3} \mathrm{CF}_{3}\right)_{\mathrm{n}} \cdot \mathrm{SiO}_{2}$ precursor 1:1. Adapted from reference [94].

The inclusion of the $\mathrm{Ag}^{\circ}$ nanoparticles inside $\mathrm{SiO}_{2}$ was also made by pyrolysis of the respective (PS-co-4-PVP) $\cdot\left(\mathrm{AgNO}_{3}\right)_{\mathrm{n}} \bullet\left(\mathrm{SiO}_{2}\right)_{\mathrm{n}}$ and chitosan $\cdot\left(\mathrm{AgNO}_{3}\right)_{\mathrm{n}} \bullet\left(\mathrm{SiO}_{2}\right)_{\mathrm{n}}$ precursors [94] Well dispersed $\mathrm{Ag}$ nanoparticles inside $\mathrm{SiO}_{2}$ were observed for the $\mathrm{Ag} / \mathrm{SiO}_{2}$ composites obtained from chitosan $\bullet\left(\mathrm{AgNO}_{3}\right) \mathrm{n} \bullet\left(\mathrm{SiO}_{2}\right)_{\mathrm{m}}$ and $(\mathrm{PS}-\mathrm{co}-4-\mathrm{PVP}) \cdot\left(\mathrm{AgNO}_{3}\right) \mathrm{n} \bullet\left(\mathrm{SiO}_{2}\right)_{\mathrm{m}}$, with particle sizes of 5 and $6 \mathrm{~nm}$, respectively.

Furthermore, $\mathrm{ZnO}$ and $\mathrm{SnO}_{2}$ were also included in silica [58]. Pyrolysis of the $\mathrm{ZnCl}_{2} \cdot$ chitosan $\cdot \mathrm{SiO}_{2}$ and $\mathrm{SnCl}_{2} \cdot$ chitosan $\cdot \mathrm{SiO}_{2}$ precursors at $800{ }^{\circ} \mathrm{C}$ under air afford mixtures of $\mathrm{Zn}_{2} \mathrm{SiO}_{4}$ and $\mathrm{SiO}_{2}$, and pure $\mathrm{SnO}_{2}$, respectively. $\mathrm{SnO}_{2}$ nanoparticles are regularly distributed inside the silica matrix.

The inclusion of $\mathrm{IrO}_{2}$ into $\mathrm{SiO}_{2}$ was performed using a combined solution of the chitosan and PVP precursors using the sol-gel method [63]. Subsequent pyrolysis of the isolated solid-state chitosan $\cdot\left(\mathrm{IrCl}_{3}\right)_{\mathrm{x}}\left(\mathrm{SiO}_{2}\right)_{\mathrm{y}}$ and PSP-4-PVP. $\left(\mathrm{IrCl}_{3}\right) \mathrm{x}\left(\mathrm{SiO}_{2}\right)_{\mathrm{y}}$ give rise to the $\mathrm{IrO}_{2} / / \mathrm{SiO}_{2}$ nanocomposites. The $\mathrm{IrO}_{2}$ particles are distributed uniformly inside the matrix of $\mathrm{SiO}_{2}$, leading to stable porous materials appropriate for high-temperature catalytic applications.

The same procedures were used for $\mathrm{Re}$ and Th. The inclusion of $\mathrm{ReO}_{3}$ into $\mathrm{SiO}_{2}$ was performed using a combined solution of the chitosan and PSP-4-PVP precursors by the sol-gel method [62]. Subsequent pyrolysis of the solid chitosan $\left(\mathrm{ReCl}_{3}\right) \times\left(\mathrm{SiO}_{2}\right)_{\mathrm{y}}$ and PSP-4-PVP. $\left(\mathrm{ReCl}_{3}\right) \mathrm{x} \cdot\left(\mathrm{SiO}_{2}\right)_{\mathrm{y}}$ precursors give rise to the $\mathrm{ReO}_{3} / / \mathrm{SiO}_{2}$ nanocomposites. The as-obtained $\mathrm{ReO}_{3}$ nanoparticles inside $\mathrm{SiO}_{2}$ are as small as $1 \mathrm{~nm}$. $\mathrm{ReO}_{3}$ nanoparticles are distributed uniformly inside the $\mathrm{SiO}_{2}$ matrix, leading to stable semiporous materials suitable for high-temperature catalytic applications. The inclusion of $\mathrm{ThO}_{2}$ inside $\mathrm{SiO}_{2}$ and $\mathrm{TiO}_{2}$ was achieved through a similar solid-state method [140-142]. The $\mathrm{ThO}_{2} / \mathrm{SiO}_{2}$ composites were prepared by pyrolysis at $800{ }^{\circ} \mathrm{C}$ under air of the chitosan $\bullet \mathrm{Th}\left(\mathrm{NO}_{3}\right)_{4} / / \mathrm{SiO}_{2}$ and PS-co-4-PVP. Th $\left(\mathrm{NO}_{3}\right)_{4} / / \mathrm{SiO}_{2}$ precursors [66]. On the other hand, $\mathrm{ThO}_{2} / \mathrm{TiO}_{2}$ composites were similarly prepared by pyrolysis at $800{ }^{\circ} \mathrm{C}$ chitosan $\cdot \mathrm{Th}\left(\mathrm{NO}_{3}\right)_{4} / / \mathrm{TiO}_{2}$ and PS-co-4$\mathrm{PVP} \cdot \mathrm{Th}\left(\mathrm{NO}_{3}\right)_{4} / / \mathrm{TiO}_{2}$ precursors. $\mathrm{ThO}_{2}$ particles exhibit a suitable dispersion inside the silica showing sizes of $250 \mathrm{~nm}$ and $950 \mathrm{~nm}$ depending on the chitosan or PS-co-4-PVP polymer precursors, respectively. SEM-EDS mapping analysis shows a regular dispersion of the thoria into the $\mathrm{SiO}_{2}$ and $\mathrm{TiO}_{2}$ matrices. The luminescent properties of the $\mathrm{ThO}_{2} / \mathrm{SiO}_{2}$ and $\mathrm{ThO}_{2} / \mathrm{TiO}_{2}$ composites show a dependence of their luminescence intensity, being the most intense with the $\mathrm{TiO}_{2}$ matrix.

On the other hand, the inclusion of $\mathrm{NiO}$ inside the $\mathrm{SiO}_{2}, \mathrm{TiO}_{2}, \mathrm{Al}_{2} \mathrm{O}_{3}, \mathrm{Na}_{4.2} \mathrm{Ca}_{2.8}\left(\mathrm{Si}_{6} \mathrm{O}_{18}\right)$ matrices was also performed by solid-state under-air pyrolysis of the: Chitosan $\cdot\left(\mathrm{NiCl}_{2} \cdot 6 \mathrm{H}_{2} \mathrm{O}\right)_{\mathrm{x}} / /$ $\mathrm{SiO}_{2}$, PS-co-4-PVP. $\left(\mathrm{NiCl}_{2}\right)_{\mathrm{x}} / / \mathrm{SiO}_{2}$, chitosan $\cdot\left(\mathrm{NiCl}_{2} \cdot 6 \mathrm{H}_{2} \mathrm{O}\right)_{\mathrm{x}} / / \mathrm{TiO}_{2}$, PS-co-4-PVP $\left(\mathrm{NiCl}_{2}\right)_{\mathrm{x}} / / \mathrm{TiO}_{2}$, chitosan $\left(\mathrm{NiCl}_{2} \cdot 6 \mathrm{H}_{2} \mathrm{O}\right)_{\mathrm{x}} / / \mathrm{Al}_{2} \mathrm{O}_{3}$, PS-co-4-PVP. $\left(\mathrm{NiCl}_{2}\right)_{x} / \mathrm{Al}_{2} \mathrm{O}_{3}$, chitosan $\left(\mathrm{NiCl}_{2} \cdot 6 \mathrm{H}_{2} \mathrm{O}\right)_{x} / / \mathrm{NiO}$ $/ \mathrm{Na}_{4.2} \mathrm{Ca}_{2.8}\left(\mathrm{Si}_{6} \mathrm{O}_{18}\right)$ and PS-co-4-PVP $\left(\mathrm{NiCl}_{2}\right)_{\times} / / \mathrm{NiO} / \mathrm{Na}_{4.2} \mathrm{Ca}_{2.8}\left(\mathrm{Si}_{6} \mathrm{O}_{18}\right)$ precursors [65]. The new composites were characterized by XRD, SEM/EDS, TEM, and HR-TEM. The size of the $\mathrm{NiO}$ nanoparticles obtained from the PSP-4-PVP precursors inside the different matrices follows the order of $\mathrm{SiO}_{2}>\mathrm{TiO}_{2}>\mathrm{Al}_{2} \mathrm{O}_{3}$. However, $\mathrm{NiO}$ nanoparticles obtained from the chitosan precursor do not present an effect on the particle size. It was found that the matrices $\left(\mathrm{SiO}_{2}, \mathrm{TiO}_{2}\right.$, $\mathrm{Al}_{2} \mathrm{O}_{3}$, and $\left.\mathrm{Na}_{4.2} \mathrm{Ca}_{2.8}\left(\mathrm{Si}_{6} \mathrm{O}_{18}\right)\right)$ have a medium effect on the band-gap energy and also on the photocatalytic methylene blue degradation. 


\section{Photocatalytic Applications}

Industrial plants generate increasing amounts of wastewaters, which often causes severe environmental problems [141,142]. Wastewaters produced in many industrial processes typically contain organic compounds that are toxic and not amenable to direct biological treatments [142]. There are huge numbers of different types of organic pollutants, including dyes, phenols, biphenyls pesticides, fertilizers, hydrocarbons, plasticizers, detergents, oils, greases, pharmaceuticals, proteins, carbohydrates, and so on [143]. Therefore, there is a great need to develop an efficient and cost-effective technique to reduce the concentration of organic pollutants before releasing the wastewaters into the aquatic environment. Currently, industrially available wastewaters treatment technologies such as adsorption and coagulation merely concentrate or separate these pollutants from water but do not completely "eliminate" or "destroy" them into biodegradable or less toxic organic compounds [144]. Other water treatments methods, such as chemical and membrane technologies, usually involve high operating costs and sometimes generate other toxic secondary pollutants [145]. Among the various physical, chemical, and biological technologies used in pollution control, including biological technologies, advanced oxidation processes such as photocatalysis are being increasingly adopted in the destruction of the organic contaminant due to their high efficiency, simplicity, suitable reproducibility, and ease of handling [146]. Heterogeneous photocatalysis possesses some critical advantages that have feasible applications in wastewater treatments, including:

(i) Ambient operating temperatures and pressure;

(ii) Complete mineralization of contaminants and their intermediates compounds without leaving secondary pollutants;

(iii) Low operating costs [146].

Among the most used photocatalyst are the nanostructured metal oxides [10,11]. However, their current preparation involves mainly in-solution methods [147-154], which present some problems in the isolation of the solid by elimination of the solvent as well as the elimination of the template and of the stabilizer [151].

Among the main applications of nanostructured metal oxides, the photocatalytic degradation of organic pollutants lies in the field of environmental remediation. The main characteristics that a suitable metal oxide photocatalytic system must include [145]:

1. An adequate band-gap;

2. Suitable morphology;

3. High surface area;

4. Stability and reusability.

Semiconductor metal oxides having a band-gap near $3.2 \mathrm{eV}$ are UV light active, while semiconductor metal oxides with a band-gap near $2.7 \mathrm{eV}$ are visible light active [142]. Metal oxides exhibiting these features, such as vanadium, chromium, titanium, zinc, tin, and cerium, follow similar primary photocatalytic processes such as light absorption, which induce a charge separation process with the consequent formation of positive holes that are able to oxidize organic substrates. In this process, a metal oxide is activated by either UV light, visible light, or a combination of both, and photoexcited electrons are promoted from the valence band to the conduction bands, forming an electron/hole pair $\left(\mathrm{e}^{-} / \mathrm{h}^{+}\right)$. The photogenerated pair $\left(\mathrm{e}^{-} / \mathrm{h}^{+}\right)$is able to reduce and/or oxidize a compound adsorbed on the photocatalyst surface. A schematic representation of these processes is shown in Figure 19. 


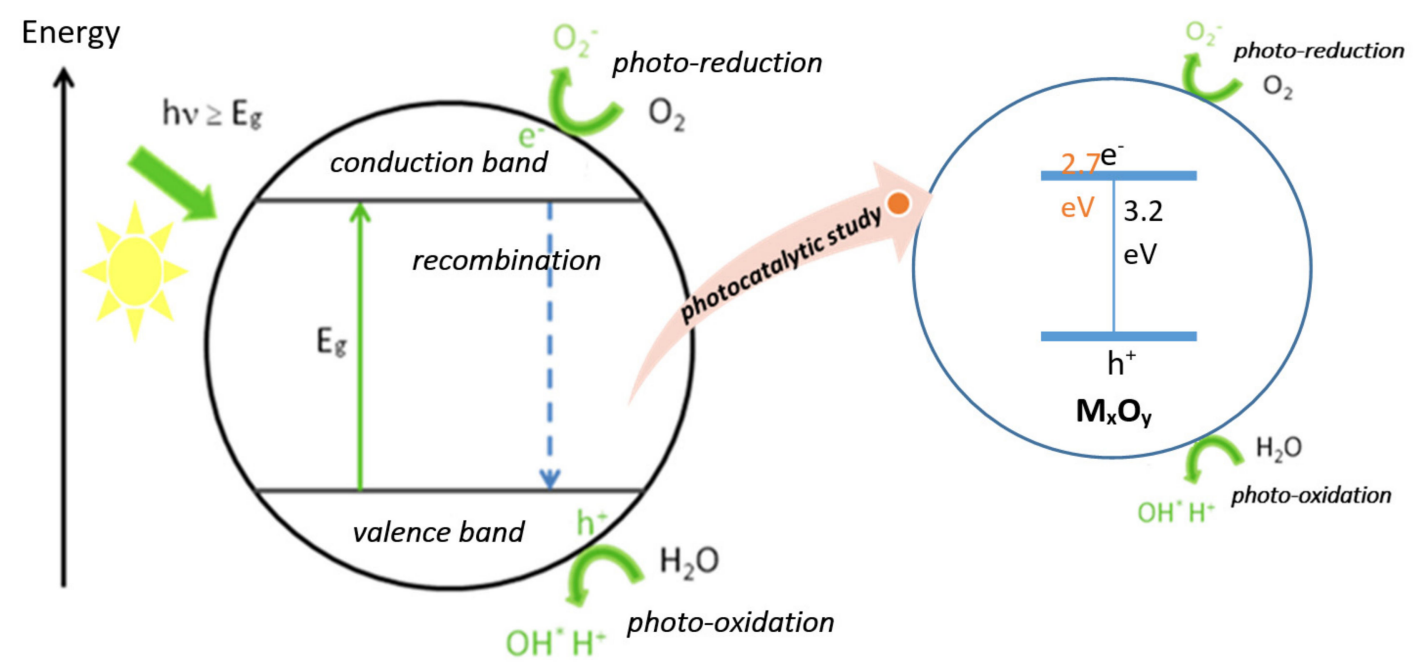

Figure 19. Photocatalytic activity of nanostructure metal oxides.

The photocatalytic activity of metal oxides comes from two sources [148]:

1. Generation of $\bullet \mathrm{OH}$ radicals by oxidation of $\mathrm{OH}^{-}$anions;

2. Generation of $\mathrm{O}_{2}{ }^{-}$radicals by reduction in $\mathrm{O}_{2}$.

Semiconductor nanostructured metal oxides have been widely used in photocatalytic redox processes because of their electronic configuration of the filled valence band (VB) and empty conduction band (CB). When exposed to a photon with energy exceeding the band-gap, $h v>E_{g}$, it generates an electron-hole pair with one electron in VB pumped into $\mathrm{CB}$, leaving a hole behind in VB. The generated holes in VB are of great oxidation capability, while the electrons in the $\mathrm{CB}$ have high reducing potential.

These highly reactive electrons and holes participate in photocatalytic organic degradation.

As mentioned above, the factors that are important for an efficient photocatalyst include an adequate band-gap, suitable morphology, high surface area, stability, and reusability. The achievement of these characteristics for a given nanostructured metal oxide will depend on its preparation method. For instance, $\mathrm{TiO}_{2}$ is one of the most used and efficient metal oxides for photocatalytic degradation of several organic dye pollutants [145]. However, its relative efficiency depends on the preparation method, which in turn determinates the band-gap, the morphology, the surface area, and their stability and reusability. In this context, our solid-state method could afford nanostructured metal oxides that can easily exhibit the above characteristics, yielding an efficient photocatalyst for the degradation of organic pollutants.

One of the advantages of the metal oxides obtained by the solid state described above is that they can be used directly in photocatalytic heterogeneous catalysis.

For all $\mathrm{TiO}_{2}$ products described in Table 1, the most effective degradant of methylene blue was the anatase obtained from the precursor (chitosan). $\left(\mathrm{TiOSO}_{4}\right.$ ) at $800^{\circ} \mathrm{C}$ [59]. This material achieved a $98 \%$ discoloration rate in only $25 \mathrm{~min}$ when the $\mathrm{pH}$ of the solution was 9.5, improving the efficiency of the standard photocatalyst Degussa P25 without the addition of other phases or dopants. Figure 20a shows the $\mathrm{c} / \mathrm{c}_{0}$ vs. irradiation time for the $\mathrm{TiO}_{2}$ from (chitosan). $\left(\mathrm{TiOSO}_{4}\right.$ ) at several temperatures. At $800{ }^{\circ} \mathrm{C}, 86.5 \%$ discoloration rate in $25 \mathrm{~min}$ was observed. Optimization of the $\mathrm{pH}$ shows a $98 \%$ discoloration at $\mathrm{pH} 9.5$, as shown in Figure 20b. From all different known $\mathrm{TiO}_{2}$ materials, the obtained using our solid-state method is one of the most efficient toward methylene blue degradation [59].

Another photocatalytic-assayed system was hematite- $\mathrm{Fe}_{2} \mathrm{O}_{3}$ [54]. The nanoparticulate material obtained from chitosan. $\left(\mathrm{FeCl}_{2}\right)_{\text {y }} 1: 1$ under the simulated sunlight (full visible spectrum) irradiation provides high rate degradation of $\mathrm{MB}$ by $73 \%$ in $60 \mathrm{~min}$ and $>94 \%$ after $150 \mathrm{~min}$, measured at $655 \mathrm{~nm}$, as seen in Figure 21. The high photocatalytic efficiency can be due, in part, to the porous morphology of the hematite- $-\mathrm{Fe}_{2} \mathrm{O}_{3}$ [54]. 
On the other hand, $\mathrm{NiO}$ as well as their $\mathrm{NiO} / \mathrm{SiO}_{2}, \mathrm{NiO} / \mathrm{TiO}_{2}, \mathrm{NiO} / \mathrm{Al}_{2} \mathrm{O}_{3}$ nanocomposites presenting band-gap values in the range $5.0-5.6 \mathrm{eV}$, see Table 2, predicts that they can be used as appropriate photocatalyst using UV irradiation [65]. In fact, $\mathrm{NiO}$ and their $\mathrm{NiO} / \mathrm{SiO}_{2}, \mathrm{NiO} / \mathrm{TiO}_{2}, \mathrm{NiO} / \mathrm{Al}_{2} \mathrm{O}_{3}$ nanocomposites exhibit a satisfactory efficient photocatalytic behavior [65]. The higher methylene blue efficiency was for the $\mathrm{NiO} / \mathrm{TiO}_{2}$ composite arising from the chitosan $\left(\mathrm{NiCl}_{2} \cdot 6 \mathrm{H}_{2} \mathrm{O}\right)_{x} / / \mathrm{TiO}_{2}$ precursor, see Table 3 . This can be due to a p-n junction that can be formed acting $\mathrm{NiO}$ as $\mathrm{p}-\mathrm{NiO}$ and $\mathrm{TiO}_{2}$ as $\mathrm{n}-\mathrm{TiO}_{2}$. Therefore, it seems that the matrix is playing a crucial role for the $\mathrm{NiO} / \mathrm{TiO}_{2}$ composite, and in this case, the $\mathrm{NiO}$ acts as the matrix rather than an active semiconductor, see Figure 22.
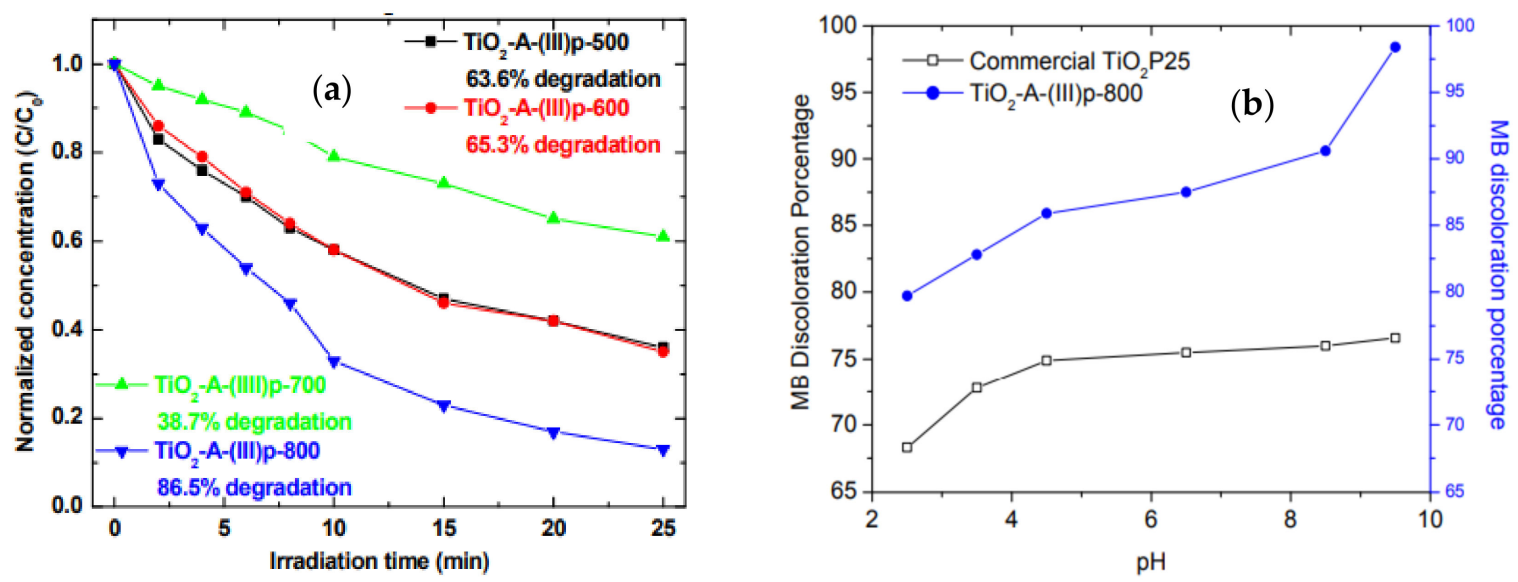

Figure 20. (a) Normalized concentration changing of $\mathrm{MB}$ as a function of time for all $\mathrm{TiO}_{2}$ photocatalyst obtained by precursors (Chitosan) $\bullet\left(\mathrm{TiOSO}_{4}\right)$ at different temperatures. (b) Effect of $\mathrm{pH}$ on $\mathrm{MB}$ $\left(1 \times 10^{-5} \mathrm{M}\right)$ discoloration using our best $\mathrm{TiO}_{2}$.

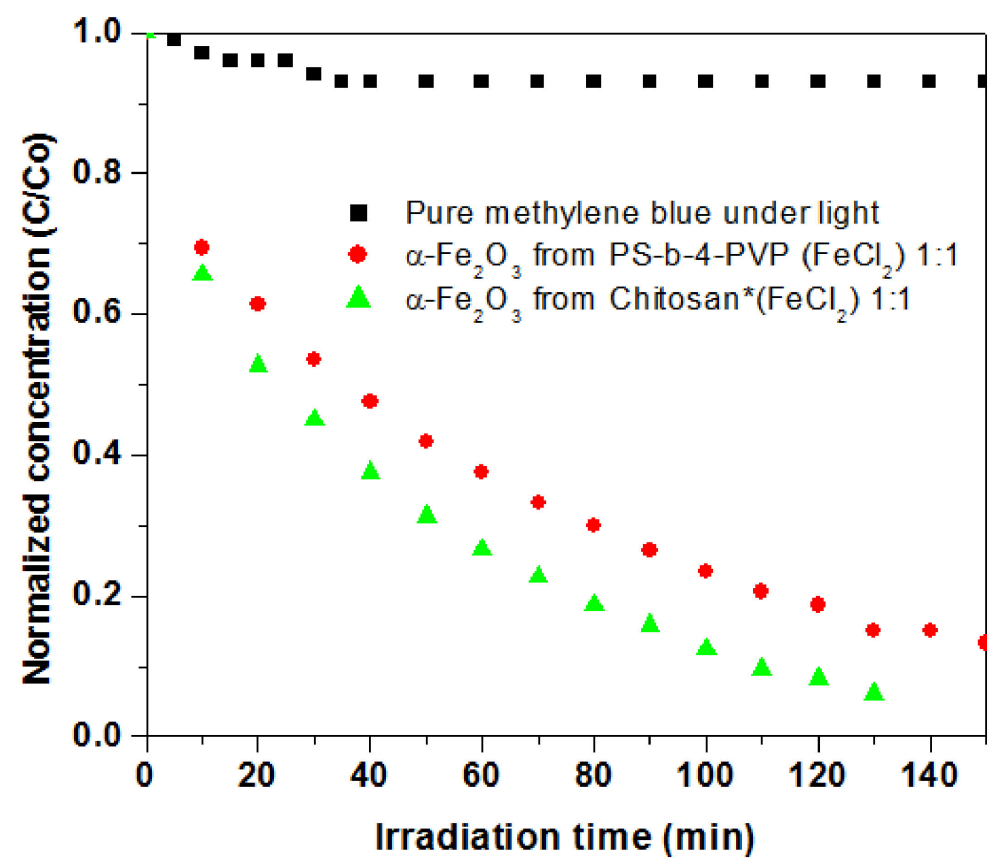

Figure 21. Normalized concentration changing of $\mathrm{MB}$ without catalyst, in the presence of a- $\mathrm{Fe}_{2} \mathrm{O}_{3} \cdot \mathrm{PS}-$ co-4-PVP and in the presence of a- $\mathrm{Fe}_{2} \mathrm{O}_{3}$. chitosan. Adapted from reference [54]. 
Table 2. $\mathrm{E}_{\mathrm{g}}$ values for $\mathrm{NiO}$ and $\mathrm{NiO}$ included in the $\mathrm{SiO}_{2}, \mathrm{TiO}_{2}, \mathrm{Al}_{2} \mathrm{O}_{3}$, and $\mathrm{Na}_{4.2} \mathrm{Ca}_{2.8}\left(\mathrm{Si}_{6} \mathrm{O}_{18}\right)$ matrices Adapted from reference [65].

\begin{tabular}{|c|c|c|}
\hline Composite & Precursor Formula & $\mathrm{Eg}(\mathrm{eV})$ \\
\hline $\mathrm{NiO}$ & Chitosan $\cdot \mathrm{NiCl}_{2}$ & 5.2 \\
\hline $\mathrm{NiO}$ & PSP-4-PVP.NiCl 2 & 5.2 \\
\hline $\mathrm{NiO} / \mathrm{SiO}_{2}$ & Chitosan $\cdot \mathrm{NiCl}_{2}$ & 5.0 \\
\hline $\mathrm{NiO} / \mathrm{SiO}_{2}$ & PSP-4-PVP-NiCl 2 & 5.5 \\
\hline $\mathrm{NiO} / \mathrm{TiO}_{2}$ & Chitosan $\cdot \mathrm{NiCl}_{2}$ & 5.2 \\
\hline $\mathrm{NiO} / \mathrm{TiO}_{2}$ & $\mathrm{PSP}-4-\mathrm{VP} \cdot \mathrm{NiCl}_{2}$ & 5.2 \\
\hline $\mathrm{NiO} / \mathrm{Al}_{2} \mathrm{O}_{3}$ & Chitosan $\cdot \mathrm{NiCl}_{2}$ & 5.4 \\
\hline $\mathrm{NiO} / \mathrm{Na}_{4.2} \mathrm{Ca}_{2.8}\left(\mathrm{Si}_{6} \mathrm{O}_{18}\right)$ & Chitosan $\cdot \mathrm{NiCl}_{2}$ & 5.6 \\
\hline
\end{tabular}

Table 3. Kinetic data for the photodegradation process of $\mathrm{MB}$ with $\mathrm{NiO}$ and $\mathrm{NiO} / \mathrm{SiO}_{2}, \mathrm{NiO} / \mathrm{TiO}_{2}$, $\mathrm{NiO} / \mathrm{Al}_{2} \mathrm{O}_{3}$, and $\mathrm{NiO} / \mathrm{Na}_{42} \mathrm{Ca}_{2.8}\left(\mathrm{Si}_{6} \mathrm{O}_{18}\right)$ composites. Adapted from reference [65].

\begin{tabular}{cc}
\hline Photocatalyst & Discoloration Rate (\%) \\
\hline $\mathrm{NiO}-\mathrm{CHITOSAN}$ & $71 \%$ \\
\hline $\mathrm{NiO}-\mathrm{PS}-4-\mathrm{PVP}$ & $68 \%$ \\
\hline $\mathrm{NiO} / \mathrm{SiO}_{2}$-CHITOSAN & $69 \%$ \\
\hline $\mathrm{NiO} / \mathrm{SiO}_{2}$-PS-4-PVP & $48 \%$ \\
\hline $\mathrm{NiO} / \mathrm{TiO}_{2}-\mathrm{CHITOSAN}$ & $91 \%$ \\
\hline $\mathrm{NiO} / \mathrm{TiO}_{2}-\mathrm{PS}-4-\mathrm{PVP}$ & $81 \%$ \\
\hline $\mathrm{NiO} / \mathrm{Al}_{2} \mathrm{O}_{3}-\mathrm{CHITOSAN}$ & $45 \%$ \\
\hline $\mathrm{NiO} / \mathrm{Na}_{4.2} \mathrm{Ca}_{2.8}\left(\mathrm{Si}_{6} \mathrm{O}_{18}\right)$ & $75 \%$ \\
\hline
\end{tabular}

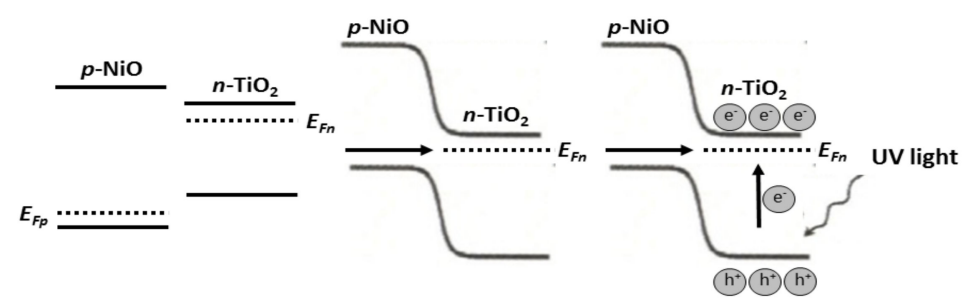

(a)

(b)

(c)

Figure 22. Schematic diagrams for (a) energy bands of $\mathrm{p}-\mathrm{NiO}$ and $\mathrm{TiO}_{2}$ before contact, (b) formation of the p-n junction and its energy diagram at equilibrium, and (c) transfer of holes from $n-\mathrm{TiO}_{2}$ to $\mathrm{p}-\mathrm{NiO}$ under UV irradiation.

We have also studied the photocatalytic behavior of $\mathrm{ReO}_{3}$ prepared from the pyrolysis of the chitosan $\left(\mathrm{ReCl}_{3}\right)_{\mathrm{X}}$ and PSP-4-PVP. $\left(\mathrm{ReCl}_{3}\right)_{\mathrm{X}}$ precursors [62]. The as-prepared $\mathrm{ReO}_{3}$ exhibits a moderated and high activity for $\mathrm{ReO}_{3}$ arising from chitosan and PSP-4-PVP precursors' respectively. The composite $\mathrm{ReO}_{3} / / \mathrm{SiO}_{2}$ prepared by solid-state pyrolysis of the chitosan $\cdot\left(\mathrm{ReCl}_{3}\right)_{\mathrm{X}}\left(\mathrm{SiO}_{2}\right)_{\mathrm{y}}$ and PSP-4-PVP. $\left(\mathrm{ReCl}_{3}\right)_{\mathrm{X}}\left(\mathrm{SiO}_{2}\right)_{\mathrm{y}}$ precursors exhibit a moderate photocatalytic activity toward the degradation of methylene blue and similar to that of $\mathrm{ReO}_{3}$, see Table 4. This is the first report of the photocatalytic activity of $\mathrm{ReO}_{3}$ and $\mathrm{ReO}_{3} / / \mathrm{SiO}_{2}$ composite. 
Table 4. Kinetic data for the photodegradation process of $\mathrm{MB}$ with $\mathrm{ReO}_{3}$ and $\mathrm{ReO}_{3} / \mathrm{SiO}_{2}$. Adapted from reference [62].

\begin{tabular}{ccc}
\hline Photocatalyst & $\begin{array}{c}\text { Photodegradation Rate } \\
\text { Constant k (10 }\end{array}$ & Discoloration Rate (\%) \\
\hline $\mathrm{ReO}_{3}$-PS-4-PVP & 2.8 & $64 \%$ \\
\hline $\mathrm{ReO}_{3}$-Chitosan & 2.8 & $53 \%$ \\
\hline $\mathrm{ReO}_{3} / \mathrm{SiO}_{2}$-PS-4-PVP & 3.7 & $67 \%$ \\
\hline $\mathrm{ReO}_{3} / \mathrm{SiO}_{2}$-Chitosan & 1.9 & $57 \%$ \\
\hline
\end{tabular}

We also tested the photocatalytic activity of $\mathrm{IrO}_{2}$ and their composite with $\mathrm{SiO}_{2}$ obtained by solid pyrolysis of the chitosan. $\left(\mathrm{IrCl}_{3}\right)_{\mathrm{X}}$, PSP-4-PVP. $\left(\mathrm{IrCl}_{3}\right)_{\mathrm{X}}$, chitosan. $\left(\mathrm{IrCl}_{3}\right)_{\mathrm{x}}\left(\mathrm{SiO}_{2}\right)_{\mathrm{y}}$, and PSP-4-PVP. $\left(\mathrm{IrCl}_{3}\right) \times\left(\mathrm{SiO}_{2}\right)_{y}$ precursors.

The oxide $\mathrm{Rh}_{2} \mathrm{O}_{3}$ and the mixture $\mathrm{Rh} / \mathrm{RhO}_{2}$ have band-gap values of 3 and $3.7 \mathrm{eV}$, respectively, so they could have photocatalytic activity using UV irradiation [64]. In fact, $\mathrm{Rh}_{2} \mathrm{O}_{3}$ and the $\mathrm{Rh} / \mathrm{RhO}_{2}$ mixture exhibit methylene blue degradation of $70 \%$ and $78 \%$ in $300 \mathrm{~min}$, respectively. To the best of our knowledge, no photodegradation of pollutants using these type Rh oxides have been reported previously.

Finally, we have measured for the first time the catalytic activity of the thoria and of their $\mathrm{ThO}_{2} / \mathrm{SiO}_{2}$ and $\mathrm{ThO}_{2} / \mathrm{TiO}_{2}$ composites. As shown in Table 5, thoria prepared from the chitosan. Th $\left(\mathrm{NO}_{3}\right)_{4}$ precursor exhibited an activity of $66 \%$ in $300 \mathrm{~min}$ while that thoria prepared from PS-co-4-PVP.Th( $\left(\mathrm{NO}_{3}\right)_{4}$ precursor presents activity of $67 \%$ degradation of $\mathrm{MB}$ in the same time. In addition, the photocatalytic efficiency of the $\mathrm{ThO}_{2} / \mathrm{SiO}_{2}$ and $\mathrm{ThO}_{2} / \mathrm{TiO}_{2}$ composites decrease significantly, as can be viewed from Table 5 . The photocatalytic activity toward methylene blue degradation follows the order $\mathrm{ThO}_{2}>\mathrm{ThO}_{2} / \mathrm{TiO}_{2}>\mathrm{ThO}_{2} / \mathrm{SiO}_{2}$, which can be due to the decrease in the active sites of the surface as a consequence of the encapsulation of the $\mathrm{ThO}_{2}$ into $\mathrm{TiO}_{2}$. An additional reason could be the porous morphology of $\mathrm{ThO}_{2}$, which is encapsulated inside the $\mathrm{SiO}_{2}$ and $\mathrm{TiO}_{2}$ matrices [66].

Table 5. Photocatalytic efficiency of the different $\mathrm{ThO}_{2}$ composites.

\begin{tabular}{cc}
\hline Photocatalyst & Discoloration Rate (\%) \\
\hline $\mathrm{ThO}_{2}$-chitosan & 67 \\
\hline $\mathrm{ThO}_{2}$-PS-4-PVP & 66 \\
\hline $\mathrm{ThO}_{2} / \mathrm{SiO}_{2}$-chitosan & 24 \\
\hline $\mathrm{ThO}_{2} / \mathrm{SiO}_{2}$-PS-4-PVP & 25 \\
\hline $\mathrm{ThO}_{2} / \mathrm{TiO}_{2}$-chitosan & 39 \\
\hline $\mathrm{ThO}_{2} / \mathrm{TiO}_{2}$-PS-4-PVP & 27 \\
\hline
\end{tabular}

\section{Probable Formation Mechanism of Nanostructures Metallic and Metal Oxides}

Although the formation mechanism of nanoparticles in solution is well known [152-154], the studies of solid-state preparation methods are limited, and the parameters controlling both the size and the morphology of the formed nanoparticles are unknown. In this regard, we have evidenced that the pyrolysis of the $\left\{\mathrm{NP}\left(\mathrm{OC}_{8} \mathrm{H}_{12}\right)_{2}\left(\mathrm{OC}_{6} \mathrm{H}_{4} \mathrm{PPh}_{2}-\mathrm{Mn}(\mathrm{CO})_{2}\left(\eta^{5}-\mathrm{C}_{5} \mathrm{H}_{4} \mathrm{Me}\right)_{2}\right\}\right.$ precursor occurs through the intermediate formation of a layered graphite host, which is formed in the first step of the thermal solid-state reaction [16]. In addition, the formation of the nanostructured $\mathrm{Mn}_{2} \mathrm{O}_{3}$ and $\mathrm{Co}_{2} \mathrm{O}_{3}$ compounds from their respective (chitosan)(MLn) ${ }_{\mathrm{x}}$, MLn $=\mathrm{MnCl}_{2}$, and $\mathrm{CoCl}_{2}$ macromolecular complexes precursors was confirmed to occur through an intermediate state, a layered graphitic carbon matrix, which was observed by HRTEM and Raman measurements [55]. More recently, the formation of $\mathrm{TiO}_{2}$ using several pyrolysis temperatures was confirmed with the formation of a graphite intermediate [59]. Considering all studies, a general mechanism is proposed, as shown in Figure 23. 


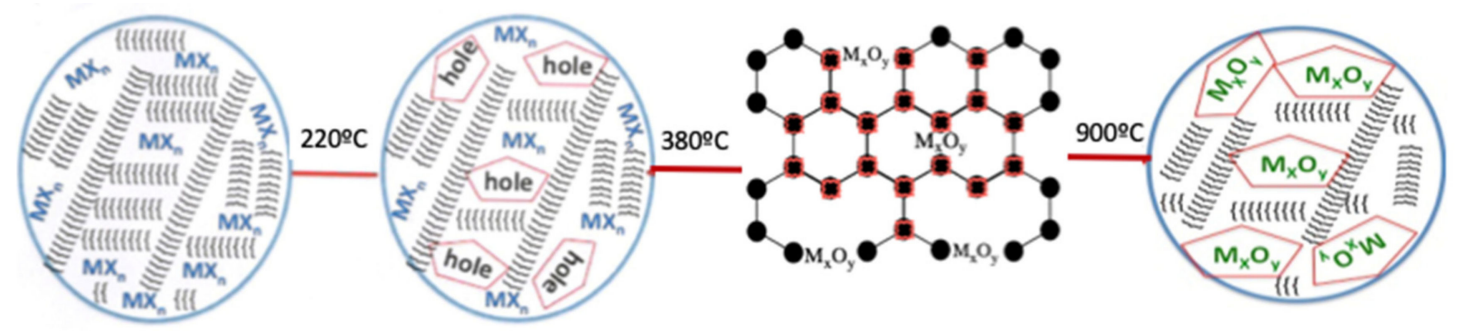

Figure 23. Schematic representation of the proposed mechanism of formation of the metal oxide nanoparticles. $\mathrm{MX}_{\mathrm{n}}$ represents the general formula of the metallic salt coordinated to the Chitosan and PSP-4-PVP polymer, $\}\}\}\}\}\}$ \} represents the Chitosan and PSP-4-PVP polymer. $\mathrm{M}_{\mathrm{x}} \mathrm{O}_{\mathrm{y}}$ represents the respective metal oxides formed inside the graphite matrix. The given temperatures are referential general values.

The first step on heating involves the formation of a 3D network [15] to produce a thermally stable matrix. This step is crucial because it offset the sublimation. In our system, the first heating step could involve a cross-linking of the Chitosan and PS-co-4-PVP polymers, giving a 3D matrix containing O-M-O and $\mathrm{H}_{2} \mathrm{~N}-\mathrm{M}-\mathrm{NH}_{2}$ links (for the chitosan polymer) and (pyridine)N-M-N(pyridine) bonds for the PS-co-4-PVP polymer. The following steps involve the starting of the organic carbonization, producing holes where the nanoparticles begin to nucleate. According to TG/DSC analysis, this occurs at $\sim 400{ }^{\circ} \mathrm{C}$ for the chitosan and $360^{\circ} \mathrm{C}$ for PS-co-4-PVP polymer matrices. In this intermediate stage, a layered graphitic carbon host (detected in our previous work [16]) acts as a template where the nanoparticles grow. After complete combustion, this template disappears but always remains carbon residues appearing as an ultrathin carbon shell around the nanoparticles [16].

\section{Concluding Remarks}

Although there are several solid-state methods to prepare nanoparticles, scarce mechanism studies have been reported, being this is a pending challenge. In this sense, control of parameters such as size and morphology of the formed nanoparticles is not known. Using the proposed solid-state method from the chitosan-MXn and PS-co-4-PVP.MXn complexes as precursors offers a reliable, general, and easy way for obtaining metal and metal oxides from all the periodic table. Using the chitosan $\bullet \mathrm{MLn} / / \mathrm{M}_{\mathrm{x}}^{\prime} \mathrm{O}_{\mathrm{y}}^{\prime}$ and PS-co4-PVP•MLn / / $\mathrm{M}^{\prime}{ }_{\mathrm{x}} \mathrm{O}^{\prime}$ precursors, $\mathrm{M} / \mathrm{M}_{\mathrm{x}}^{\prime} \mathrm{O}_{\mathrm{y}}^{\prime}$ and $\mathrm{M}_{\mathrm{x}} \mathrm{O}_{\mathrm{y}} / \mathrm{M}^{\prime}{ }_{\mathrm{x}} \mathrm{O}_{\mathrm{y}}^{\prime}$ composites with $\mathrm{M}_{\mathrm{x}}^{\prime} \mathrm{O}_{\mathrm{y}}$ solid matrices can be easily obtained. However, a most detailed study of the effect of the inclusion of the metal and metal oxides nanoparticles inside the $\mathrm{M}^{\prime}{ }_{\mathrm{x}} \mathrm{O}_{\mathrm{y}}$ matrix is still pending. In spite of that, several metal oxides obtained by the described solid-state method exhibit a satisfactory photocatalytic toward contaminant dyes as methylene blue. In any case, most of them need to be double-checked to obtain a general conclusion about the photocatalytic effectiveness of these oxides in order to improve them. It is also envisaged that the nanostructured metal oxides described here could significantly contribute to environmental decontamination.

Author Contributions: C.D., M.L.V. and M.Á.L.-B. conceptualized, wrote the manuscript. All authors have read and agreed to the published version of the manuscript.

Funding: Department of Chemistry, Faculty of Sciences, University of Chile; Grant PID2019107106RB-C32 funded by MCIN/AEI/10.13039/501100011033.

Conflicts of Interest: The authors declare no conflict of interest. 


\section{References}

1. Hornyak, G.; Tibbals, H.F.; Dutta, J.; Moore, J. Introduction to Nanoscience and Nanotechnology; CRC Press Taylor and Francis: Boca Raton, NY, USA, 2009.

2. Altavilla, C.; Ciliberto, E. Inorganic Nanoparticles; CRC Press Taylor and Francis: Boca Raton, NY, USA, 2011.

3. Rao, C.N.; Muller, A.; Cheetham, A.K. The Chemistry of Nanomaterials; Wiley-VCH: Weinheim, Germany, 2004.

4. Edelstein, A.S.; Cammarata, R.C. Nanomaterials, Synthesis and Applications; Institute of Physics Publishing: Bristol, UK, 2002.

5. Cao, G. Nanostructures and Nanomaterial, Synthesis, Properties and Applications; Imperial College Press: London, UK, 2011.

6. Díaz, C.; Valenzuela, M.L. Metallic Nanostructures Using Oligo and Polyphosphazenes as Template or Stabilizer in Solid State. In Encyclopedia of Nanoscience and Nanotechnology; Nalwa, H.S., Ed.; American Scientific Publishers: Valencia, CA, USA, 2010; Volume 16, pp. 239-256.

7. Walter, E.C.; Ng, K.; Zach, M.P.; Penner, R.M.; Favier, F. Electronic Devices from electrodeposited metal nanowires. Microelectron. Eng. 2002, 61-62, 555-561. [CrossRef]

8. Walkers, G.; Parkin, I.P. The Incorporation of noble nanoparticles into hast matrix thin films, synthesis, characterization and applications. J. Mater. Chem. 2009, 19, 574-590. [CrossRef]

9. Scott, C.A. Epitaxial growth and properties of doped transition metal and complex oxide films. Adv. Mater. 2010, $21,219-248$.

10. Teo, B.; Sun, X. Silicon-Based Low-Dimensional Nanomaterials and Nanodevices. Chem. Rev. 2010, 107, 1454-1532. [CrossRef] [PubMed]

11. Khomutov, G.B.; Kislov, V.V.; Antipina, M.N.; Gainutdinov, R.V.; Gubin, S.P.; Obydenov, A.Y.; Pavlov, S.A.; Rakhnyanskaya, A.A.; Sergeev-Cherenkov, A.N.; Soldatov, E.S.; et al. Interfacial nanofabrication strategies in development of new functional nanomaterials and planar supramolecular nanostructures for nanoelectronic and nanotechnology. Microelectron. Eng. 2003, 69, 373-383. [CrossRef]

12. Diaz, C.; Valenzuela, M.L.; Bobadilla, D. Bimetallic Au/Ag metal superstructures from macromolecular metal complexes in solid-state. J. Chil. Chem. Soc. 2013, 58, 1194-1997. [CrossRef]

13. Díaz, C.; Valenzuela, M.L. Small-Molecule and High-Polymeric Phosphazenes containing oxypyridine side groups and their organometallic derivatives, Useful precursors for metal nanostructured materials. Macromolecules 2006, 39, 103-111. [CrossRef]

14. Díaz, C.; Valenzuela, M.L. Organometallic Derivatives of Polyphosphazenes as Precursors for Metallic Nanostructured Materials. J. Inorg. Organomet. Polym. 2006, 16, 419-435. [CrossRef]

15. Díaz, C.; Valenzuela, M.L.; Zuñiga, L.; O’Dwyer, C. Organometallic derivatives of cyclotriphosphazene as precursors of Nanostructured metallic materials, A new solid state Method. J. Inorg. Organomet. Polym. Mater. 2009, 19, 507-520. [CrossRef]

16. Díaz, C.; Valenzuela, M.L.; Lavayen, V.; O’Dwyer, C. Layered Graphitic Carbon Host Formation during Liquid-free Solid State Growth of Metal Pyrophosphates. Inorg. Chem. 2012, 51, 6228-6236. [CrossRef]

17. Díaz, C.; Valenzuela, M.L.; Carriedo, G.A.; Zuñiga, L.; O’Dwyer, C. Polymer/Trimer/Metal Complex Mixtures as Precursors of Gold Nanoparticles, Tuning the Morphology in the Solid-State. J. Inorg. Organomet. Polym. 2012, 22, 447-454.

18. Díaz, C.; Valenzuela, M.L.; Cáceres, S.; O’Dwyer, C. Solution and surfactant-free growth of supported high index facet SERS active anoparticles of rhenium by phase demixing. J. Mater. Chem. A 2013, 1, 1566-1572.

19. Díaz, C.; Valenzuela, M.L.; Cáceres, S.; O’Dwyer, C.; Diaz, R. Solvent and stabilizer free growth of Ag and Pd nanoparticles using Metallic salts/cyclotriphosphazenes mixtures. Mater. Chem. Phys. 2013, 143, 124-132. [CrossRef]

20. Díaz, C.; Valenzuela, M.L.; Zuñiga, L.; O’Dwyer, C. Solid State Pathways to Complex Shape Evolution and Tunable Porosity During Metallic Crystal Growth. Sci. Rep. 2013, 3, 2642.

21. Díaz, C.; Valenzuela, M.L. Organometallic-Metallic-Cyclotriphosphazene Mixtures, Solid-State Method for Metallic Nanoparticle Growth. In Nanostructures, Properties, Production Methods and Application; Nova Science Publishers: New York, NY, USA, 2013; Chapter 5.

22. Díaz, C.; Valenzuela, M.L. A General Solid-State approach to metallic, metal oxides and Phosphates Nanoparticles. In Advances in Chemical Research; Nova Science Publishers: New York, NY, USA, 2011.

23. Díaz, C.; Valenzuela, M.L. A general Solid-State approach to Metallic, Metal oxides and Phosphate nanoparticles. Gold Nanoparticles, Properties Synthesis and Fabrication. In Solution and Solid State Methods to Prepare Au Nanoparticles: A Comparison; Chow, P.E., Ed.; Nova Science Publishers: New York, NY, USA, 2010; Chapter 14.

24. Larsen, T.H.; Sigman, M.; Ghezelbash, A.; Christopher-Doty, R.; Korgel, B.A. Solventless Synthesis of Copper Sulfide Nanorods by Thermolysis of a Single Source Thiolate-Derived Precursor. J. Am. Chem. Soc. 2003, 125, 5638-5639. [CrossRef] [PubMed]

25. Sigman, M.; Ghezelbash, A.; Hanrath, T.; Saunders, A.E.; Lee, F.; Korgel, B.A. Solventless Synthesis of $\mathrm{Monodisperse} \mathrm{Cu}_{2} \mathrm{~S}$ Nanorods, Nanodisks, and Nanoplatelets. J. Am. Chem. Soc. 2003, 125, 16050-16057. [CrossRef] [PubMed]

26. Ghezelbash, A.; Sigman, M.; Korgel, B.A. Solventless Synthesis of Nickel Sulfide Nanorods and Triangular Nanoprisms. Nano Lett. 2004, 4, 537-542. [CrossRef]

27. Sigman, M.; Korgel, B.A. Solventless Synthesis of $\mathrm{Bi}_{2} \mathrm{~S}_{3}$ (Bismuthinite) Nanorods, Nanowires, and Nanofabric. Chem. Mater. 2005, 17, 1655-1660. [CrossRef]

28. Han, Y.C.; Cha, H.G.; Kim, C.h.W.; Kim, Y.H.; Kang, Y.S. Synthesis of Highly Magnetized Iron Nanoparticles by a Solventless Thermal Decomposition Method. J. Phys. Chem. C 2007, 111, 6275-6280. [CrossRef]

29. Farhadi, S.; Roostaei-Zaniyani, Z. Preparation and characterization of NiO nanoparticles from thermal decomposition of the $\mathrm{Ni}(\mathrm{en})_{3}\left(\mathrm{NO}_{3}\right)_{2}$ complex, A facile and low-temperature route. Polyhedron 2011, 30, 971-975. [CrossRef] 
30. Li, X.; Zhang, X.; Li, Z.; Qian, Y. Synthesis and characteristics of NiO nanoparticles by thermal decomposition of nickel dimethylglyoximate rods. Solid State Commun. 2006, 137, 581-584. [CrossRef]

31. Davar, F.; Salavati-Niasari, M.; Mir, N.; Saberyan, K.; Monemzadeh, M. Thermal decomposition route for synthesis of $\mathrm{Mn}_{3} \mathrm{O}_{4}$ nanoparticles in presence of a novel precursor. Polyedron 2010, 29, 1747-1753. [CrossRef]

32. Yanh, Z.; Zhang, Y.; Zhang, W.; Wang, X.; Qian, Y.; Weng, X.; Yang, S. Nanorods of manganese oxides, Synthesis, characterization and catalytic application. J. Solid State Chem. 2006, 179, 679-684.

33. Soofivand, F.; Salavati-Niasari, M.; Mohandes, F. Novel precursor-assisted synthesis and characterization of zinc oxide nanoparticles/nanofibers. Mater. Lett. 2013, 98, 55-58. [CrossRef]

34. Farhadi, S.; Pouzare, K.; Sadedhinejad, S. Simple preparation of ferromagnetic $\mathrm{CO}_{3} \mathrm{O}_{4}$ nanoparticles by thermal dissociation of the $\mathrm{Co}^{\mathrm{II}}\left(\mathrm{NH}_{3}\right)_{6}\left(\mathrm{NO}_{3}\right)_{2}$ complex at low termperature. J. NanoStruct. Chem. 2013, 3, 16. [CrossRef]

35. Randhawa, B.S.; Gandotra, K. A comparative study on the thermal decomposition of some transition metal carboxylates. J. Therm. Anal. Calorim. 2006, 85, 417-424. [CrossRef]

36. Chunxiang Li Weng, K.L. Thermolysis of Polymeric $\mathrm{Ru}(\mathrm{CO})_{4 . n}$ to Metallic Ruthenium, Molecular Shape of the Precursor Affects the Nanoparticle Shape. Langmuir 2008, 24, 12040-12041.

37. Nelson, J.M.; Nguyen, P.; Petersen, R.; Rengel, H.; Macdonald, P.M.; Lough, I.J.; Manners, I.; Raju, N.P.; Greedan, J.E.; Barlow, S.; et al. Thermal Ring-Opening Polymerization of Hydrocarbon-Bridged 2.Ferrocenophanes, Synthesis and Properties of Poly(ferrocenylethylene)s and Their Charge-Transfer Polymer Salts with Tetracyanoethylene. Chem. Eur. J. 1997, 3, 573-584. [CrossRef]

38. Tang, B.Z.; Petersen, R.; Foucher, D.A.; Lough, A.; Coombs, N.; Sodhi, R. Novel Ceramic and Organometallic Depolymerization Products from Poly(ferrocenyIsilanes) via Pyrolysis. J. Chem. Soc. Chem. Commun. 1993, 523-525. [CrossRef]

39. Chang, B.S.; Brijith, T.; Chen, J.; Tevis, I.D.; Karanja, P.; Çınar, S.; Venkatesh, A.; Rossini, A.J.; Thuo, M.M. Ambient synthesis of nanomaterials by in situ heterogeneous metal/ligand reactions. Nanoscale 2019, 11, 14060-14069. [CrossRef] [PubMed]

40. Li, C.; Zhong, Z.; Leong, W.K. Organometallic Clusters As Precursors for Metallic Nanoparticles, Effect of Cluster Size, Ligand Set, and Decomposition Method. Langmuir 2008, 24, 10427-10431. [CrossRef] [PubMed]

41. Cai, B.; Akkiraju, K.; Mounfield, W.P.; Wang, Z.; Li, X.; Huang, B.; Yuan, S.; Su, D.; Roman-Leshkov, Y.; Shao-Horn, Y. Solid-State Gelation for Nanostructured Perovskite Oxide Aerogel. Chem. Mater. 2019, 31, 9422-9429. [CrossRef]

42. Wang, B.; Zhang, C.; Zheng, W.; Zhang, Q.; Bao, Z.; Kong, L.; Li, L. Large-Scale Synthesis of Highly Luminescent Perovskite Nanocrystals by Template-Assisted Solid-State Reaction at 800. Chem. Mater. 2020, 32, 308-314. [CrossRef]

43. Mao, Y.; Banerjee, S.; Wong, S.S. Large-Scale Synthesis of Single-Crystalline Perovskite Nanostructures. J. Am. Chem. Soc. 2003, 125, 15718-15719. [CrossRef]

44. Schmitt, W.; Hill, J.P.; Malik, S.; Volkert, C.A.; Ichinose, I.; Anson, C.; Powell, A.K. Thermolysis of a Hybrid Organic-Inorganic Supramolecular Coordination Assembly, Templating the Formation of Nanostructured Fibrous Materials and Carbon-Based Microcapsules. Angew. Chem. Int. Ed. 2005, 44, 7048-7053. [CrossRef] [PubMed]

45. Reda, G.M.; Fan, H.; Tian, H. Room-temperature solid state synthesis of $\mathrm{Co}_{3} \mathrm{O}_{4} / \mathrm{ZnO} \mathrm{p}-\mathrm{n}$ heterostructure and its photocatalytic activity. Adv. Powder Technol. 2017, 28, 953-963. [CrossRef]

46. Nalluri, S.R.; Nagarjuna, R.; Patra, D.; Ganesan, R.; Balaj, G. Large Scale Solid-state Synthesis of Catalytically Active Fe $3 \mathrm{O}_{4} @ \mathrm{M}$ $(\mathrm{M}=\mathrm{Au}, \mathrm{Ag}$ and $\mathrm{Au}-\mathrm{Ag}$ alloy) Core-shell Nanostructures. Sci. Rep. 2019, 9, 6603. [CrossRef]

47. Dey, A.; Zubko, M.; Kusz, J.; Reddy, V.R.; Banerjee, A.; Bhattacharjee, A. Thermal synthesis of Hematite nanoparticles, Structural, magnetic and morphological characterizations. Int. J. Nano Dimens. 2020, 11, 188-198.

48. Das, R.; Pachfule, P.; Banerjee, R.; Poddar, P. Metal and Metal oxide nanoparticle synthesis from metal organic frameworks (MOFs), finding the border of metal and metal oxides. Nanoscale 2012, 4, 591-599. [CrossRef] [PubMed]

49. Rong, K.; Wei, J.; Huang, L.; Fang, Y.; Dong, S. Synthesis of low dimensional hierarchical transition metal oxides via a direct deep eutectic solvent calcining method for enhanced oxygen evolution catalysis. Nanoscale 2020, 12, 20719-20725. [CrossRef]

50. Zhu, J.; Jiang, Y.; Lu, Z.; Zhao Ch Xie, L.; Chen, L.; Duan, J. Single-crystal $\mathrm{Cr}_{2} \mathrm{O}_{3}$ nanoplates with differing crystalinities, derived from trinuclear complexes and embedded in a carbon matrix, as an electrode material for supercapacitors. J. Colloid Interface Sci. 2017, 498, 351-363. [CrossRef] [PubMed]

51. Yuan, Y.; Chen, L.; Yang, R.; Lu, X.; Peng, H.; Luo, Z. Solid-state synthesis and characterization of core-shell CoFe $\mathrm{O}_{4}-\mathrm{carbon}$ composite nanoparticles from a heterometallic trinuclear complex. Mater. Lett. 2012, 71, 123-126. [CrossRef]

52. Díaz, C.; Valenzuela, M.L.; Lavayen, V.; Mendoza, K.; Peña, O.; O’Dwyer, C. Nanostructured copper oxides and phosphates from a new solid-state route. Inorg. Chim. Acta 2011, 377, 5-11. [CrossRef]

53. Díaz, C.; Platoni, S.; Molina, A.; Valenzuela, M.L.; Geaney, H.; O’Dwyer, C. Novel Solid-State Route to Nanostructured Tin, Zinc and Cerium Oxides as Potential Materials for Sensors. J. Nanosci. Nanotechnol. 2014, 14, 7648-7653. [CrossRef]

54. Diaz, C.; Barrera, G.; Segovia, M.; Valenzuela, M.L.; Osiak, M.; O’Dwyer, C. Solvent-less method for efficient photocatalytic $\alpha-\mathrm{Fe}_{2} \mathrm{O}_{3}$ nanoparticles for using macromolecular polymeric precursors. New J. Chem. 2016, 40, 6768-6776. [CrossRef]

55. Diaz, C.; Valenzuela, M.L.; Laguna, M.A.; Orera, A.; Bobadilla, D.; Abarca, S.; Peña, O. Synthesis and Magnetic Properties of Nanostructured metallic $\mathrm{Co}, \mathrm{Mn}$ and $\mathrm{Ni}$ oxide materials obtained from solid-state macromolecular complex precursors. RSC Adv. 2017, 7, 27729-27736. [CrossRef]

56. Diaz, C.; Valenzuela, M.L.; Bobadilla, D.; Laguna-Bercero, M.A. Bimetallic Au//Ag Alloys Inside $\mathrm{SiO}_{2}$ using a solid-state method. J. Clust. Chem. 2017, 28, 2809-2815. [CrossRef] 
57. Diaz, C.; Valenzuela, M.L.; Garcia, C.; De la Campa, R.; Soto, A.-P. Solid-state synthesis of pure and doped lanthanides oxide nanomaterials by using polymer templates. Study of their luminescent properties. Mater. Lett. 2017, 209, 111-114. [CrossRef]

58. Diaz, C.; Valenzuela, M.L.; Segovia, M.; De la Campa, R.; Soto, A.-P. Solution, Solid-State Two Step Synthesis and Optical Properties of $\mathrm{ZnO}$ and $\mathrm{SnO}$ Nanoparticles and Their Nanocomposites with $\mathrm{SiO}_{2}$. J. Clust. Sci. 2018, 29, 251-266. [CrossRef]

59. Allende, P.; Laguna, M.A.; Barrientos, L.; Valenzuela, M.L.; Diaz, C. Solid State tuning Morphology, Crystal Phase and Size through Metal Macromolecular Complexes and Its Significance in the Photocatalytic Response. ACS Appl. Energy Mater. 2018, 1, 3159-3170. [CrossRef]

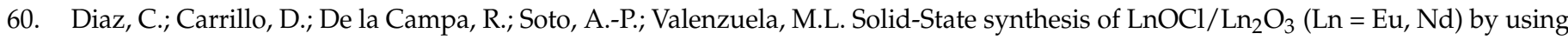
chitosan and PS-co-P4VP as polymeric supports. J. Rare Earth 2018, 36, 1326-1332. [CrossRef]

61. Allende, P.; Barrientos, L.; Orera, A.; Laguna-Bercero, M.A.; Salazar, N.; Valenzuela, M.L.; Diaz, C. TiO $/ \mathrm{SiO}_{2} \mathrm{Composite}_{\text {for }}$ Efficient Protection of UVA and UVB Rays Through of a Solvent-Less Synthesis. J. Clust. Sci. 2019, 30, 1511-1517. [CrossRef]

62. Diaz, C.; Valenzuela, M.L.; Cifuentes-Vaca, O.; Segovia, M.; Laguna-Bercero, M.A. Incorporation of $\mathrm{Nanostructured} \mathrm{ReO}_{3}$ in Silica Matrix and Their Activity Toward Photodegradation of Blue Methylene. J. Inorg. Organomet. Polym. Mater. 2020, 30, 1726-1734. [CrossRef]

63. Diaz, C.; Valenzuela, M.L.; Cifuentes-Vaca, O.; Segovia, M.; Laguna-Bercero, M.A. Iridium nanostructured metal oxide, its inclusion in Silica matrix and their activity toward Photodegradation of Methylene Blue. Mater. Chem. Phys. 2020, 252, 123276-123286. [CrossRef]

64. Diaz, C.; Valenzuela, M.L.; Cifuentes-Vaca, O.; Segovia, M. Polymer precursors effect in the macromolecular metal-polymer on the $\mathrm{Rh} / \mathrm{RhO}_{2} / \mathrm{Rh}_{2} \mathrm{O}_{3}$ phase using solvent-less synthesis and its photocatalytic activity. J. Inorg. Organomet. Polym. Mater. 2020, 30, 4702-4708. [CrossRef]

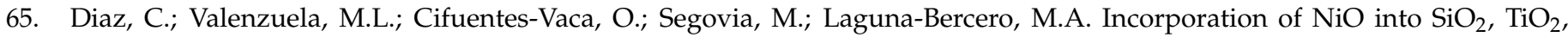
$\mathrm{Al}_{2} \mathrm{O}_{3}$, and $\mathrm{Na}_{4.2} \mathrm{Ca}_{2.8}\left(\mathrm{Si}_{6} \mathrm{O}_{18}\right)$ Matrices, Medium Effect on the Optical Properties and Catalytic Degradation of Methylene Blue. Nanomaterials 2020, 10, 2470. [CrossRef]

66. Diaz, C.; Valenzuela, M.L.; Laguna-Bercero, M.A.; Mendoza, K.; Cartes, P. Solventless preparation of thoria, their inclusion inside $\mathrm{SiO}_{2}$ and $\mathrm{TiO}_{2}$, their luminiscent properties and their photocataltytic behavior. ACS Omega 2021, 6, 9391-9400. [CrossRef] [PubMed]

67. Chen, X.; Mao, S.S. Titanium Dioxide Nanomaterials, Synthesis, Properties, Modifications, and Applications. Chem. Rev. 2007, 107, 2891-2959. [CrossRef] [PubMed]

68. Ismail, A.A.; Bahnemannb, D.W. Mesoporous titania photocatalysts, preparation, characterization and reaction mechanisms. J. Mater. Chem. 2011, 21, 11686-11707. [CrossRef]

69. Wang, Y.; Cao, G. Synthesis and Enhanced Intercalation Properties of Nanostructured Vanadium Oxides. Chem. Mater. 2006, 18, 2787-2804. [CrossRef]

70. Mao, C.J.; Pan, H.C.; Wu, X.C.; Zhu, J.J.; Chen, H.Y. Sonochemical Route for Self-Assembled $\mathrm{V}_{2} \mathrm{O}_{5}$ Bundles with Spindle-like Mosphology and their Novel Application in Serum Albumin Sensing. J. Phys. Chem. 2006, 110, 14709-14713.

71. Avansi, W.; Ribeiro, C.; Leite, E.; Mastelaro, V. Vanadium Pentoxide Nanostructured, An Effective Control of Morphology and Crystal Strucutred in Hydrothermal Conditions. Cryst. Growth Des. 2009, 9, 3626-3631. [CrossRef]

72. Diaz, C.; Barrera, G.; Segovia, M.; Valenzuela, M.L.; Osiak, M.; O’Dwyer, C. Crystallizing Vanadium Pentoxide Nanostructures in the Solid State using Modified Block co-Polymer and Chitosan Complexes. J. Nanomater. 2015, 2015, 105157. [CrossRef]

73. Fei, H.L.; Liu, M.; Zhou, H.J.; Sun, P.C.; Ding, D.T.; Chen, T.H. Synthesis of $\mathrm{V}_{2} \mathrm{O}_{5}$ micro-architectures via in situ generation of single-crystalline nanoparticles. Solid State Sci. 2009, 11, 102-107. [CrossRef]

74. Díaz, C.; Valenzuela, M.L.; Yutronic, N.; Villalobos, V.; Barrera, G. Nanostructured VOx/VO(PO 4$)_{\mathrm{n}}$ Using Solid-State Vanadium Containing Phosphazene Precursors, A Uselful Potential Bi-Catalyst System. J. Clust Sci. 2011, 22, 693-704. [CrossRef]

75. Zhou, Y.; Qiu, Z.; Lu, M.; Zhang, A.; Ma, Q. Preparation and characterization of $\mathrm{V}_{2} \mathrm{O}_{5}$ macro-plates. Mater. Lett. 2007, 61, 4073-4075. [CrossRef]

76. Diaz, C.; Valenzuela, M.L.; Zepeda, L.; Herrera, P.; Valenzuela, C. General group VI transition nanostructured metal oxides and their inclusion into solid matrices by a solution-solid approach. J. Chil. Chem. Soc. 2021, 66. in press.

77. Han, Y.; Chen, F.; Zhong, Z.; Ramesh, K.; Chen, L.; Widjaja, E. Controlled Synthesis, Characterization, and Catalytic Properties of Mn2O3 and Mn3O4 Nanoparticles Supported on Mesoporous Silica SBA-15. J. Phys. Chem. B 2006, 110, 24450-24456. [CrossRef]

78. Laurent, S.; Forge, D.; Port, M.; Roch, A.; Robic, C.; Vander Elst, L.; Muller, R. Magnetic Iron Oxide Nanoparticles, Synthesis, Stabilization, Vectorization, Physicochemical Characterizations and Biological Applications. Chem. Rev. 2008, 108, 2064-2110. [CrossRef]

79. Teja, A.; Koh, P.Y. Synthesis propieties and applications of magnetic iron oxide nanoparticles. Prog. Cryst. Growth Charact. Mater. 2009, 55, 22-45. [CrossRef]

80. Patra, A.K.; Kundu, S.K.; Bhaumik, A.; Kim, D. Morphology evolution of single-crystalline hematite nanocrystals: Magnetically recoverable nanocatalysts for enhanced facet-driven photoredox activity. Nanoscale 2016, 8, 365. [CrossRef] [PubMed]

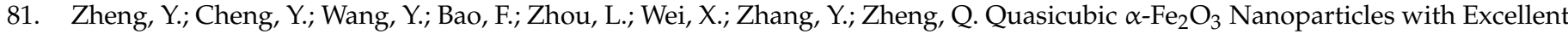
Catalytic Performance. J. Phys. Chem. 2006, 110, 3093-3097. [CrossRef]

82. Hua, J.; Gengsheng, J. Hydrothermal synthesis abd characterization of monodispere $\alpha-\mathrm{Fe}_{2} \mathrm{O}_{3}$ Nanoparticles. Mater. Lett. 2009, 63, 2725-2727. [CrossRef] 
83. Liu, Y.; Yu, C.; Dai, W.; Gao, X.; Qian, H.; Hu, Y.; Hu, X. One-post solvothermal synthesis of multi-shelled $\alpha-\mathrm{Fe}_{2} \mathrm{O}_{3}$ hollow spheres with enhaced visible-light photocatalytic activity. J. Alloy. Compd. 2013, 551, 440-443. [CrossRef]

84. Jiu, J.; Ge, Y.; Li, X.; Nie, L. Preparation of $\mathrm{Co}_{3} \mathrm{O}_{4}$ nanoparticles by a polymer conbution route. Mater. Lett. 2002, 54, 260-263. [CrossRef]

85. Li, Y.; Tan, B.; $\mathrm{Wu}, \mathrm{Y}$. Mesoporous $\mathrm{Co}_{3} \mathrm{O}_{4}$ Nanowires Arrays for Lithium Ion Batteries with High Capacity and rate Capability. Nano Lett. 2008, 8, 265-270. [CrossRef]

86. Deng, J.; Kang, L.; Bai, G.; Li, Y.; Li, P.; Liu, X.; Yang, Y.; Gao, F.; Liang, W. Solution combustion synthesis of cobalt oxides $\left(\mathrm{Co}_{3} \mathrm{O}_{4}\right.$ and $\mathrm{Co}_{3} \mathrm{O}_{4} / \mathrm{CoO}$ ) nanoparticles as supercapacitor electrode materials. Electrochim. Acta 2014, 132, 127-135. [CrossRef]

87. Salvati-Niasari, M.; Khansari, A.; Davar, F. Synthesis and characterization of cobalt oxides nanoparticles by thermal process. Inorg. Chem. Acta 2009, 362, 4937-4942. [CrossRef]

88. Nassar, M.Y.; Ahmed, I.S. Hydrothermal synthesis of cobalt carbonates using different counter ions, An efficient precursor to nano-sized cobalt oxide $\left(\mathrm{Co}_{3} \mathrm{O}_{4}\right)$. Polyhedron 2011, 30, 2431-2437. [CrossRef]

89. Palacios-Hernandez, P.; Hirata-Flores, G.; Contreras-Lopez, O.; Mendoza-Sanchez, M.; Valeriano-Arreola, I.; Gonzalez-Vergara, E.; Mendez-Rojas, M. Synthesis of $\mathrm{Cu}$ and $\mathrm{Co}$ metal oxide nanoparticles from thermal decomposition of tastrate complexes. Inorg. Chem. Acta 2012, 392, 277-282. [CrossRef]

90. Kalam, A.; Al-Sehemi, A.; Al-Shihri, A.; Du, G.; Tokeer, A. Synthesis and Characterization if NiO nanoparticles by thermal decomposition of nickel linoleate and their optical properties. Mater. Charact. 2012, 68, 77-81. [CrossRef]

91. Wang, C.; Li, J.; Liang, X.; Zhang, Y.; Guo, G. Photocatalytic organic pollutants degradation in metal-organic frameworks. Energy Environ. Sci. 2014, 7, 2831-2867. [CrossRef]

92. Ukoba, K.O.; Eloka-Eboca, A.C.; Inambao, F.L. Review of nanostructured NiO thin film deposition using the spray pyrolysis technique. Renew. Sustain. Energy Rev. 2018, 82, 2900-2915. [CrossRef]

93. Rowashden-Omary, M.; Lopez-Luzuriaga, J.M.; Rashdan, M.; Elbjeirami, O.; Monge, M.; Rodriguez-Castillo, M.; Laguna, A. Golden Metallopolymers with an Active T State via Coordination of Poly(4-vinyl)pyridine to Pentahalophenyl-Gold (I) Precursors. J. Am. Chem. Soc. 2009, 131, 3824-3825. [CrossRef]

94. Diaz, C.; Valenzuela, M.L.; Soto, K.; Laguna-Bercero, M.A. Incorporation of Au and Ag Nanostructures inside SiO 2 . J. Chilean Chem. Soc. 2019, 64, 4502-4506. [CrossRef]

95. Tappan, B.; Steiner, S.; Luther, E. Nonporous Metal Foams. Angew. Chem. Int. Ed. 2010, 49, 4544-4565. [CrossRef]

96. Yaqoob, A.A.; Umar, K.; Nasir, M.; Ibrahim, M. Silver nanoparticles, various methods of synthesis, size afecting factors and their potential applications-A review. Appl. Nanosci. 2020, 10, 1369-1378. [CrossRef]

97. Syafiuddin, A.; Salmiati Salim, M.R.; Hong Kueh, A.B.; Hadibarata, T.; Nure, H.A. Review of Silver Nanoparticles, Research Trends, Global Consumption, Synthesis, Properties, and Future Challenges. J. Chin. Chem. Soc. 2017, 64, 732-756. [CrossRef]

98. Chen, A.; Holt-Hindle, P. Platinum-Based Nanostructured Materials, Synthesis, Properties and Applications. Chem. Rev. 2010, 110, 3767-3804. [CrossRef]

99. Diaz, C.; Valenzuela, M.L.; Baez, R.; Segovia, M. Solid State Morphology and Size Tuning of Nanostructured Platinum Using Macromolecular Complexes. J. Chil. Chem. Soc. 2015, 60, 2986-2990. [CrossRef]

100. Wu, J.; Qi, L.; You, H.; Gross, A.; Li, J.; Yang, H. Icosahedral Platinum Alloy Nancrystals with Enhanced Electrocatalytic activities J. Am. Chem. Soc. 2012, 134, 11880-11883. [CrossRef]

101. Leong, G.J.; Schulze, M.C.; Strand, M.B.; Maloney, D.; Frisco, S.L.; Dinh, H.N.; Pivovar, B.; Richards, R.M. Shape-directed platinum nanoparticle synthesis, nanoscale design of novel catalysts. Appl. Organomet. Chem. 2014, 28, 1-17. [CrossRef]

102. Peng, H.; Yang, H. Designer platinum nanoparticles, Control of shape, composition in alloy, nanostrucutred and electrocatalytic property. Nano Today 2009, 4, 143-164. [CrossRef]

103. Chen, J.; Lim, B.; Lee, E.P.; Xia, Y. Shape-controlled synthesis of platinum nanocrystals for catalytic and electrocatalytic applications. Nano Today 2009, 4, 81-95. [CrossRef]

104. Cotton, F.A.; Wilkinson, G. Chapter 22 and 30. In Advanced Inorganic Chemistry; John Wiley and Sons: New York, NY, USA, 1980

105. Jin, R. The impacts of nanotechnology on catalysis by precious metal nanoparticles. Nanotechnol. Rev. 2012, 1, 31-56. [CrossRef]

106. Liu, L.; Corma, A. Metal Catalysts for Heterogeneous Catalysis: From Single Atoms to Nanoclusters and Nanoparticles. Chem. Rev. 2018, 118, 4981-5079. [CrossRef]

107. Chen, R.S.; Korotcov, A.; Huiang, A.S.; Tsai, D. One-dimensional conductive $\mathrm{IrO}_{2}$ nanocrystals. Nanotechnology 2006, $17,67-87$. [CrossRef]

108. Woo, H.; Shim, H.S.; Myung, J.H.; Lee, C. Annealing effect on the structural properties of $\operatorname{IrO}_{2}$. Vacuum 2008, 82, $1400-1403$.

109. Ortel, E.; Reier, T.; Strasser, P.; Kraehnert, R. Mesoporous film template by PEO-PB-PEO block-copolymers, Self-Assembly, Cristalización behaviour and electrocatalytic performance. Chem. Mater. 2011, 23, 3201-3209. [CrossRef]

110. Zhao, Y.; Hernandez, E.A.; Vargas-Barbosa, N.M.; Dysart, J.L.; Mallouk, T.E. A high yield Synthesis of ligand-free iridium oxide nanoparticles with high electrocatalytic activity. J. Phys. Chem. Lett. 2011, 2, 402-406. [CrossRef]

111. Brewer, D.; Wicajksana, J.; Maria, A.; Kingon, S. Franzen, Investigation of the electrical and optical properties of iridium oxide by reflectance FTIR spectroscopy and density functional theory calculations. Chem. Phys. 2005, 313, 25-31. [CrossRef]

112. Xu, D.; Diao, P.; Jin, T.; Wu, Q.; Liu, X.; Guo, X.; Gong, H.; Li, F.; Xiang, M.; Ronghai, Y. Iridium oxide nanoparticles and Iridium/Iridium Oxide Nanocompósites, Photochemical Fabrication and Application in Catalytic Rediction of Notrophenol. ACS Appl. Interfaces 2015, 7, 16738-16749. [CrossRef] [PubMed] 
113. Biswas, K.; Rao, C.N. Synthesis and characterization of Nano crystals of oxide metals $\mathrm{RuO}_{2}, \mathrm{IrO}_{2}$, and $\mathrm{ReO}_{3}$. J. Nanosci. Nanotechnol. 2007, 7, 1969-1974. [CrossRef] [PubMed]

114. Lee, Y.M.; Suntivich, J.; May, K.J.; Perry, E.E.; Shao, H. Synthesis and activities of Rutile $\mathrm{IrO}_{2}$ and $\mathrm{RuO}_{2}$ nanoparticles for oxygen evolution in acid alkaline solutions. J. Phys. Chem. Lett. 2011, 2, 402-406. [CrossRef]

115. Quinson, J. Surfactant-Free Precious Metal Colloidal Nanoparticles for Catalysis. Front. Nanotechnol. 2021, 3, 770281. [CrossRef]

116. Fernandez-Garcia, M.; Martinez-Arias, A.; Hanson, J.; Rodriguez, C. Nanostructured Oxides in Chemistry, Characterization and Properties. J. Am. Chem. Rev. 2004, 104, 4063-4104. [CrossRef]

117. Kim, Y.L.; Ha, Y.; Lee, N.S.; Kim, J.G.; Baik, J.M.; Le, C.; Yoon, K.; Lee, Y.; Kim, M.H. Hybrid architecture of rhodium oxide nanofibers and ruthenium oxide nanowires for electrocatalysts. J. Alloy. Compd. 2016, 663, 574-580. [CrossRef]

118. Bai, J.; Han, S.-H.; Peng, R.; Zheng, J.-H.; Jiang, J.-X.; Chen, Y. Ultrathin Rhodium Oxide Nanosheet Nanoassemblies, Synthesis, Morphological Stability, and Electrocatalytic Application. ACS. Appl. Mater Interfaces 2017, 9, 17195-17200. [CrossRef]

119. Shimura, K.; Kawai, H.; Yoshida, T.; Yoshida, H. Simultaneously photodeposited rhodium metal and oxide nanoparticles promoting photocatalytic hydrogen production. Chem. Commun. 2011, 47, 8958-8960. [CrossRef] [PubMed]

120. Saric, A.; Popovic, S.; Music, S. Formation of crystalline phases by thermal treatment of amorphous rhodium hydrous oxide. Mater. Lett. 2002, 55, 145-151. [CrossRef]

121. Saric, A.; Popovic, S.; Trojko, R.; Music, S. The thermal behavior of amorphous rhodium hydrous oxide. J. Alloys Compd. 2011, 320, 140-148. [CrossRef]

122. Kibis, L.S.; Stadnichenko, A.I.; Koscheev, S.V.; Zaikovskii, V. Boron in A.I. XPS Study of Nanostructured Rhodium Oxide Film Comprising $\mathrm{Rh}_{4}{ }^{+}$Species. J. Phys. Chem. 2016, 120, 1942-19150.

123. Tricoli, A.; Righettoni, M.; Dupont, L.; Teleki, A. Semiconductor Gas Sensors, Dry Synthesis and Application. Angew. Chem. Int. Ed. 2010, 49, 7632-7659. [CrossRef]

124. Wang, H.; Rogach, A.L. Hierarchical $\mathrm{SnO}_{2}$ Nanostructures, Recent Advances in Desing, Synthesis and Applications. Chem. Mater. 2004, 26, 123-133. [CrossRef]

125. Ahmad, M.; Zhu, J. ZnO based advanced functional nanostructures, synthesis, properties and applications. J. Mater. Chem. 2011, 21, 599-614. [CrossRef]

126. Li, H.; Wang, X.; Huang, D.; Chen, G. Recent advances of lanthanide-doped upconversion nanoparticles for biological applications. Nanotechnology 2020, 31, 072001. [CrossRef]

127. Qin, X.; Xu, J.; Wu, Y.; Liu, X. Energy-Transfer Editing in Lanthanide-Activated Upconversion Nanocrystals: A Toolbox for Emerging Applications. ACS Cent. Sci. 2019, 5, 29-42. [CrossRef]

128. Binnemans, K. Lanthanide-Based Luminescent Hybrid Materials. Chem. Rev. 2009, 109, 4283-4374. [CrossRef]

129. Bunzli, J.C. Benefiting from the Unique Properties of Lanthanide Ions. Acc Chem Res. 2006, 39, 53-61. [CrossRef] [PubMed]

130. Dong, H.; Sun, L.D.; Yan, C.H. Basic understanding of the lanthanide related up conversion emissions. Nanoscale 2013, 5, 5703-5714. [CrossRef] [PubMed]

131. Si, R.; Zhang, Y.W.; You, L.P.; Yan, C. Rare-Earth Nanopolyhedra, Nanoplates and Nanodisks. Angew. Chem. Int. Ed. 2005, 44, 3256-3260. [CrossRef] [PubMed]

132. Kort, K.R.; Banerjee, S. Shape-Controlled Synthesis of Well-Defined Matlockite LnOVl (Ln, La, Ce, Gd, Dy) Nanocrystals by a Novel Non-Hydrolytic Approach. Inorg. Chem. 2011, 50, 5539-5544. [CrossRef]

133. Du, Y.P.; Zhang, Y.W.; Sun, L.D.; Yan, C.H. Atomically Efficient Synthesis of Self Assembled Monodisperse and Ultrathin Lanthanide Oxychloride Nanoplates. J. Am. Chem. Soc. 2009, 131, 3162-3163. [CrossRef] [PubMed]

134. Cotton, A.; Wilkinson, G.; Murillo, C.A.; Bochmann, M. Chapter 20. In Advanced Inorganic Chemistry; John Wiley and Sons: New York, NY, USA, 1999.

135. Lin, Z.W.; Kuang, Q.; Lian, W.; Jiang, Z.Y.; Xie, Z.X.; Huang, R.B.; Zheng, L.S. Preparation and Optical Properties of ThO ${ }_{2}$ and Eu-Doped $\mathrm{ThO}_{2}$ Nanotubes by the Sol-Gel Method Combined with Porous Anodic Aluminum Oxide Template. J. Phys. Chem. B 2006, 110, 23007-23011. [CrossRef]

136. Hudry, D.; Apostolidis, C.; Walter, O.; Gouder, T.; Courtois, E.; Kubel, C.; Meyer, D. Non-aqueous Synthesis of Isotropic and Anisotropic Actinide Oxide Nanocrystals. Chem. Eur. J. 2012, 18, 8283-8287. [CrossRef]

137. Hudry, D.; Apostolidis, C.; Walter, O.; Gouder, H.; Courtois, E.; Kubel, C.; Meyer, D. Controlled Synthesis of Thorium and Uranium Oxide Nanocrystals. Chem. Eur. J. 2013, 19, 5297-5305. [CrossRef]

138. Tripathi, V.K.; Narajan, R. Sol-Gel Synthesis of High-Purity Actinide Oxide $\mathrm{ThO}_{2}$ and Its Solid Solutions with Technologically Important Tin and Zinc Ions. Inorg. Chem. 2016, 55, 12798-12806. [CrossRef]

139. Armelao, L.; Barreca, D.; Bottaro, G.; Gasparotto, A.; Gross, S.; Maragnob, C.; Tondello, E. Recent trends on nanocomposites based on $\mathrm{Cu}, \mathrm{Ag}$ and Au clusters: A closer look. Coord. Chem. Rev. 2006, 250, 1294-1314. [CrossRef]

140. Liu, S.; Han, M.Y. Silica-Coated Metal Nanoparticles. Chem. Asian J. 2010, 5, 36-45. [CrossRef] [PubMed]

141. Zhang, Y.; Mei, J.; Yan, C.; Liao, T.; Bell, J.; Sun, Z. Bioinspired 2D Nanomaterials for Sustainable Applications. Adv. Mater. 2019, 32, 1902806. [CrossRef]

142. Adeyemo, A.A.; Adeoye, I.O.; Bello, O.S. Metal organic frameworks as adsorbents for dye adsorption, overview, prospects and future challenges Toxicol. Environ. Chem. 2012, 94, 1845-1863.

143. Ali, I.; Asim, M.; Khan, T.A. Low cost adsorbents for the removal of organic pollutants from wastewater. J. Environ. Manage. 2012, 113, 267-276. [CrossRef] [PubMed] 
144. Padmanabhan, O.P.; Sreekumar, K.; Sengupta, P.; Dey, G.; Werrier, K. Nano-crystalline titanium dioxide formed by reactive plasma synthesis. Vacuum 2006, 80, 1252-1255. [CrossRef]

145. Gaya, U.I.; Abdullah, A.H. Heterogeneous photocatalytic degradation of organic contaminants over titanium dioxide, A review of fundamentals, progress and problems. J. Photochem. Photobiol. C 2008, 9, 1-12. [CrossRef]

146. Chong, M.N.; Jin, B.; Chow, C.W.; Saint, C. Recent developments in photocatalytic water treatment technology: A review. Water Res. 2010, 44, 2997-3027. [CrossRef]

147. Ray, C.; Pai, T. Recent advances of metal-metal oxide nanocomposites and their tailored nanostructures in numerous catalytic applications. J. Mater. Chem. 2017, 5, 9465-9478. [CrossRef]

148. Preeti, S.; Abdullah, M.M.; Saiga, I. Role of Nanomaterials and Their Applications as Photo-catalst and Sensor: A review. Nano Res. Appl. 2016, 2, 1-10.

149. Nikam, A.V.; Prasad, B.L.V.; Kulkarnia, A.A. Wet Chemical Synthesis of Metal Oxide Nanoparticles, A Review. Cryst. Eng. Comm. 2018, 20, 5091-5107. [CrossRef]

150. Oska, G. Metal oxide nanoparticles, synthesis, characterization and application. J. Sol.-Gel. Sci. Techn. 2006, 37, 161-164. [CrossRef]

151. Guo, H.; Li, H.; Fernandez, D.; Willis, S.; Jarvis, K.; Henkelman, G.R.; Humphrey, S.M. Stabilizer-Free CuIr Alloy Nanoparticle Catalysts. Chem. Mater. 2019, 31, 10225-10235. [CrossRef]

152. Mozaffari, S.; Li, W.; Thompson, C.; Ivanov, S.; Seifert, S.; Lee, B.; Kovarik, L.; Karim, A. Colloidal nanoparticle size control, experimental and kinetic modeling investigation of the ligand-metal binding role in controlling the nucleation and growth kinetics. Nanoscale 2017, 9, 13772-13785. [CrossRef] [PubMed]

153. Nguyen, T.; Thah, T.K.; Maclean, N.; Mahiddine, S. Mechanisms of Nucleation and Growth of Nanoparticles in Solution. Chem. Rev. 2014, 114, 7610-7630.

154. Finney, E.; Finke, R. Nanocluster nucleation and growth kinetic and mechanistic studies, A review emphasizing transition-metal nanoclusters. J. Colloid Interface Sci. 2008, 317, 351-374. [CrossRef] [PubMed] 